\title{
Akran Zorbalığını Önlemede Okul Tabanlı Müdahale Programları: Sistematik Derleme
}

\author{
School-Based Intervention Programs in Preventing Peer Bullying: A Systematic Review
}

$$
\text { Aynur UYSAL TORAMAN[1] Şafak DAĞHAN[2] Ökkeş KISA[3] }
$$

Başvuru Tarihi:12 Mayıs 2021

Bu sistematik derlemede, öğrencilerin akran zorbalığı davranıșını önlemeye yönelik okul temelli eğitim programlarının etkililiğini değerlendirmek üzere yapılmış randomize kontrollü ve yarı deneysel araştırmaların sonuçları doğrultusunda elde edilen kanıtlar incelenmiștir. Derlemede "Pubmed, Wiley Interscience, Sciencedirect ve Academic Search Complete (EBSCOHOST) veri tabanından erişilen toplam dört veri tabanından ulaşılabilen, Ocak 2016- Ocak 2021 yılları arasında yapılan araştırmalar incelenmiştir. Bu veri tabanlarında İngilizce olarak "bullying, violence, school health, nursing, children, training, intervention, prevention" anahtar kelimeleri ile tarama yapılmıștır. Bu bağlamda; araștırmaya dahil edilme kriterlerine uyan 51 çalıșma sistematik derleme kapsamında değerlendirilmiştir. Dahil edilen araştırmaların 36'sı yarı deneysel, 15'i randomize kontrollü deneysel araștırma tasarımına sahiptir. Bu müdahale araştırmalarında, akran eğitimi, iletişimi güçlendirmek, ebeveyni eğitime dahil etme, öğretmenleri eğitim sürecine katmak, oyun temelli programlar, modele dayalı programlar yer almıștır. Elde edilen araștırma sonuçlarına göre farklı kültürlerde ve eğitim sistemlerinde yapılmış okul temelli uygulanan eğitim programlarının zorbalık davranışını önlemede etkili olduğu saptanmıştır. Özellikle İlkokul, ortaokul ve liseler, çalışmaların etkili olduğu alanlardır. Bu sistematik derlemede incelenen çalışmalar okul rehberlik ve psikolojik danışmanları, psikologlar, sosyal hizmet uzmanları, halk sağlığı hemşirelerine ve okul hemşirelerine rehberlik edebilir. Bununla birlikte okullarda zorbalık davranışını önleme programlarının etkisini değerlendirmek için modellere dayalı, ebeveyn, okul görevlilerinin dahil edildiği ve disiplinlerarası kanıta dayalı çalıșmalara ihtiyaç bulunmaktadır.

Anahtar Kelimeler: zorbalık, şiddet, okul sağlı̆̆ı, hemşirelik, çocuk, eğitim, müdahale, önleme

Accepted Date:21 June 2021

This systematic review was conducted to evaluate the efficiency of school-based education programs to prevent the peer bullying behaviors of students, and the results and evidence obtained from randomized controlled and quasi-experimental studies were examined in this respect. In the review, the studies that were conducted between January 2016 and January 2021, which could be accessed from a total of four databases at Pubmed, Wiley Interscience, Sciencedirect, and Academic Search Complete (EBSCOHOST) database, were examined. These databases were searched in English with the keywords "bullying, violence, school health, nursing, children, training, intervention, prevention". In this context, a total of 51 studies that met the inclusion criteria were evaluated in the scope of this systematic review. A total of 36 of these studies were conducted in quasi-experimental design, and 15 were in randomized controlled research design. There were peer education intervention studies along with strengthening communication studies, intended to include parents in education, including teachers in the education process with game-based programs and modelbased programs. According to the results of the study, it was determined that school-based training programs applied in different cultures and education systems were effective in preventing bullying behaviors. Especially primary, secondary, and high schools are the areas where studies were effective. The studies that were reviewed in this systematic review can guide school psychological consultants, psychologists, social workers, public healthcare nurses and school nurses. However, there is a need for model-based, interdisciplinary evidence-based studies including parents and school staff to evaluate the effects of bullying behavior prevention programs in schools.

Keywords: bullying, violence, school health, nursing, children, training, intervention, prevention

[1] Prof. Dr.| Ege Üniversitesi| Hemșirelik Fakültesi | Halk Sağlı̆̆ı Hemșireliği | İzmir | Türkiye | ORCID: 0000-0001-8176-4042

[2] Prof. Dr.| Ege Üniversitesi| Hemșirelik Fakültesi | Halk Sağlığı Hemșireliği | İzmir | Türkiye | ORCID: 0000-0003-3805-6416

[3] Doktora Öğrencisi | Ege Üniversitesi| Hemşirelik Fakültesi | Halk Sağlığı Hemşirelik ABD| İzmir | Türkiye | ORCID: 0000-0003-4933-0943| okkeskisa22@gmail.com

Humanistic Perspective - 2021, Cilt 3, Sayı 2, Sayfa 359-399 


\section{GíRiş}

O kullar, çocukların aile ve ev ortamından sonra onların hayatlarını şekillendiren en önemli kurumlardır. Eğitim süreçlerinde, çocuklar sağlıklı yaşam davranışlarını kazanmakta ve düşünme yetenekleri geliştirmektedir. Okula devam eden çocuklar, çocuk işçiliği, çocuk sömürgesi, şiddet ve çocuk evliliği risklerinden korunmuş olacaktır. Bununla birlikte, zaman zaman okullarda öğrenme, iyi arkadaşlık ilişkileri yerine şiddet, saldırgan davranış, dışlanma ve zorbalık gibi zararlı ilişkiler de kurulmaktadır (Evgin ve Bayat, 2020; United Nations International Children's Emergency, 2018; WHO, 2019). Önemli bir halk sağlığı sorunu olan zorbalık "Bir öğrencinin veya öğrencilerin bir başka öğrenciyi ya da öğrencileri kasıtll, sürekli veya eşit olmayan güç dengesizliği çerçevesinde olumsuz etkilere maruz bırakması" olarak tanımlanmıştır (Centers for Disease Control and Prevention, 2020; Olweus, 2003; Srabstein ve Leventha, 2010). Zorbalık, vurma, tekme atma gibi davranışlardan oluşan fiziksel zorbalık; isim takma, alay etme, topluluk içinde küçük düşürme davranışlarından oluşan sözel zorbalık ve teknoloji yoluyla kişinin kişiliğine, malına zarar vermeyle tehdit etme ve/veya gerçekleştirmesi davranışları da siber zorbalık olarak sınıflandırılmıştır (CDC, 2020). Zorba öğrenciler, saldırgan, şiddete meyilli, kendini güçlü gösterme, az empati kurma, endişeli ve güvensiz yüz ifadesine sahip olma, başkalarına zarar ve acı vermekten memnun olma, antisosyallik, zayıf ebeveyn ilişkileri, okul kurallarına uymama gibi karakteristik özelliklere sahiptir (Olweus, 1994; Banks, 1997). Zorbalığa maruz kalan öğrencilerin kaygı, yalnızlık, kızgınlık, grup dışına itilme ve çaresizlik duyguları yaşadıkları, okula gitmek istememe, okulda devamsızlıklarının arttığı, evde kalmayı tercih ettiği, akademik başarılarının ve özsaygılarının düştüğü, bazı kronik hastalıkların ortaya çıkması, hatta intihara kalkışma sebebi olabileceği ileri sürülmektedir (Bowes, 2019; Midgett vd., 2018; Pişkin, 2002). Küresel düzeyde zorbalık prevalansında farklı tahminler bulunmakla birlikte genel olarak \%13 ile \%75 arasında olduğu belirtilmiştir. (CDC, 2014). Zorbalık davranışı, en sık ortaokullar (\%28) olmak üzere, liselerde (\%16), karma okullarda (\%12) ve ilkokullarda (\%9) yaşanmaktadır (CDC, 2020). Dünya çapında 13-15 yaş arası üç öğrenciden birinin fiziksel kavgaya karıştığı, çocukların yarısının okul ve çevresinde akran şiddetine maruz kaldığı ve bu durumun yedi trilyon dolarlık bir maliyete neden olduğu belirtilmektedir (UNICEF, 2018). Organisation for Economic Co-operation and Development (OECD) PISA 2015 yılı raporuna göre; Türkiye'deki öğrencilerin \%18.6'si ayda en az birkaç kez herhangi bir zorbalık türüne maruz kaldığı, \%9.2'si başka öğrenci tarafından ayda en az birkaç kez dalga geçildiği ve \% 4.5'i başka öğrenci tarafından ayda en az birkaç kez vurma ya da itip kakmaya maruz kaldığı tespit edilmiştir (OECD, 2015).

Dünya genelinde okullarda zorbalığı önlemek için çeşitli çalışmalar yapılmaktadır. Dünya Sağlık Örgütü (2019) tarafından okullarda zorbalık davranışının önlemesine yönelik yayınlanan 
raporda, zorbalık davranışını önlemede yaşam becerilerini geliştirmek, çocuklara güvenli davranışları öğretmek, sosyal ve kültürel normları değiştirmek için mücadele ve eşit ilişkilere teşvik olmak üzere üç temel strateji benimsenmiştir (WHO, 2019). Türkiye'de zorbalığı önlemek için genellikle okul temelli çalışmalara yoğunlaşılmakla birlikte (Karataş, 2011; Albayrak, 2016; Avşar ve Ayaz Alkaya, 2018) son yıllarda siber zorbalık hakkında çalışmaların sayısı artmıştır (Akyüz ve Koç, 2020; Altundağ, 2018; Nedim Bal ve Kahraman, 2015; Özbay, 2017; Yurdakul, 2020).

Zorbalık davranışının oluşmasında sosyal çevre, aile ve okul iklimi gibi birçok etken rol oynamaktadır. Bundan dolayı zorbalık davranışını önlemede okul psikolojik danışmanları, psikologlar, hemşireler, sosyal hizmet uzmanları gibi multidisipliner ekip çalışmasına ihtiyaç bulunmaktadır (Akcan ve Ergun, 2019; Arslan ve Akın, 2016; Yelboğa ve Koçak, 2019). Halk sağlığı hemşirelerinin okul sağlığında önemli bir role sahip olduğu bilinmektedir (Avşar ve Ayaz Alkaya, 2018). Halk sağlığı hemşireleri eğitici, danışman, savunucu, değişim ajanı olma ve liderlik rollerini kullanarak okullarda akran zorbalığının önlenmesinde etkin olabilir. Ayrıca geliştirdikleri programlarla okul, aile, öğrenci ve öğretmen arasında bütüncül bir çevre oluşturmada etkin rol alabilirler (Avşar ve Ayaz Alkaya, 2018; Salmeron ve Christian, 2016). Halk sağlığı hemşiresi zorbalığın okullarda önlenmesi için yeterli bilgi düzeyine, zorba, kurban, zorba-mağdur ve izleyiciler üzerinde etkilerini, gözlem yapma yeteneği, okul personeline ve öğrencilere eğitim verme, zorbalığa maruz kalabilecek engelli ve obez gibi dezavantajlı grupları tanımlayabilme, etkili iletişim becerisine sahip olma, aileleri okullarda uygulanan programlara dahil edebilme ve önleme programları yapabilme becerilerine sahip olmalıdır (Özbey ve Başdaş, 2020). Bu sistematik derlemenin amacı, okullarda zorbalık davranışını önlemeye yönelik okul temelli eğitim programlarının içeriğini sunmak, etkilerini incelemek ve okul sağlığı hizmetlerine rehberlik etmesini sağlamaktır. Bu amaç doğrultusunda aşağıdaki sorulara cevap aranmıştır.

1. 2016-2021 yılları arasında zorbalık davranışını önleyen okul tabanlı yarı deneysel ve deneysel araştırmalar nelerdir?

2. Araştırma sonuçlarının kant düzeyi nedir?

3. Araştırmalarda sorunun çözümüne yönelik gerçekleştirilen okul sağlığı ve hemşirelik girişimleri açık olarak belirtilmiş mi?

\section{YÖNTEM}

$\mathrm{Bu}$ araştırma bir sistematik derleme çalışması olarak tasarlanmıştır. Sistematik derleme, alanında uzman kişilerce ulaşılan en iyi araştırma kanıtını tespit etmek için benzer yöntemlerle yapılmış birçok araştırmanın yapılandırılmış ve kapsamlı bir sentezidir. Bunula birlikte araştırılan bir soruya yanıt bulmak için, o alanda yapılmış çalışmalar incelenerek belirli bir 
çerçevede dahil edilme ve dışlanma kriterleri kullanılarak elde edilen bulguların sentez edilmesidir. Sistematik derlemeler, çok bilimsel bilgi içermesi ve daha güçlü kanıtları sunması yönünden önemlidirler (Karaçam, 2013). Bu derlemenin özetlenmesinde, sistematik incelemeler için geçerli ve güvenilir bir kılavuz olan "Sistematik derleme ve meta-analiz çalışmalarının raporlandırılmasında göz önünde bulundurulması gereken maddelerle ilgili kontrol listesi" (Preferred reporting items for sistematik reviews and metaanalyses statement-PRISMA) kullanılmıştır (The PRISMA Statement, 2021).

\section{İşlem}

Çalıșma, konu ile ilgili yayınların, elektronik veri tabanlarında geriye dönük taranması ile yapılmıştır. Bu kapsamda, PUBMED, Wiley Online Library, Sciencedirect ve Ege Üniversitesi Kütüphanesi bilgi ağındaki sağlık bilimleri ile ilişskili yayınlara erişim sağlayan 10 veri tabanından tabanında biri olan Academic Search Complete (EBSCOHOST) veri tabanını kullanılarak kapsamlı bir literatür taraması yapılmıștır. Bu veri tabanlarında 1 Ocak 2016 ve 1 Ocak 2021 yılları arasında yapılan çalışmalar "bullying, violence, nursing school health, children, training, intervention, prevention" anahtar kelimeleriyle taranmıştır. Belirlenen anahtar kelimelerle yapılan tarama sonucunda, Pubmed (7 Sonuç), Sciencedirect (110 Sonuç), Wiley Online Library (375 Sonuç) ve Academic Search Complete (EBSCOHOST) (978 sonuç) veri tabanlarında tarih, akademik dergiler, randomize kontrollü araştırmalar, müdahale araştırmaları, okul tabanlı araştırmalar şeklinde kısıtlamalara gidilerek 1470 çalışmaya ulaşılmıştır. Bu 1470 çalışmadan randomize ve yarı-deneysel toplam 90 çalışma bulunmuş fakat bu çalışmalardan 39'si tam metin olarak ulaşılmadığından araştırmadan çıkartılarak toplam 51 tane randomize kontrollü ve yarı-deneysel çalışma incelenmiştir. Bu çalışmalar Şekil 1'de açıklanmaktadır.

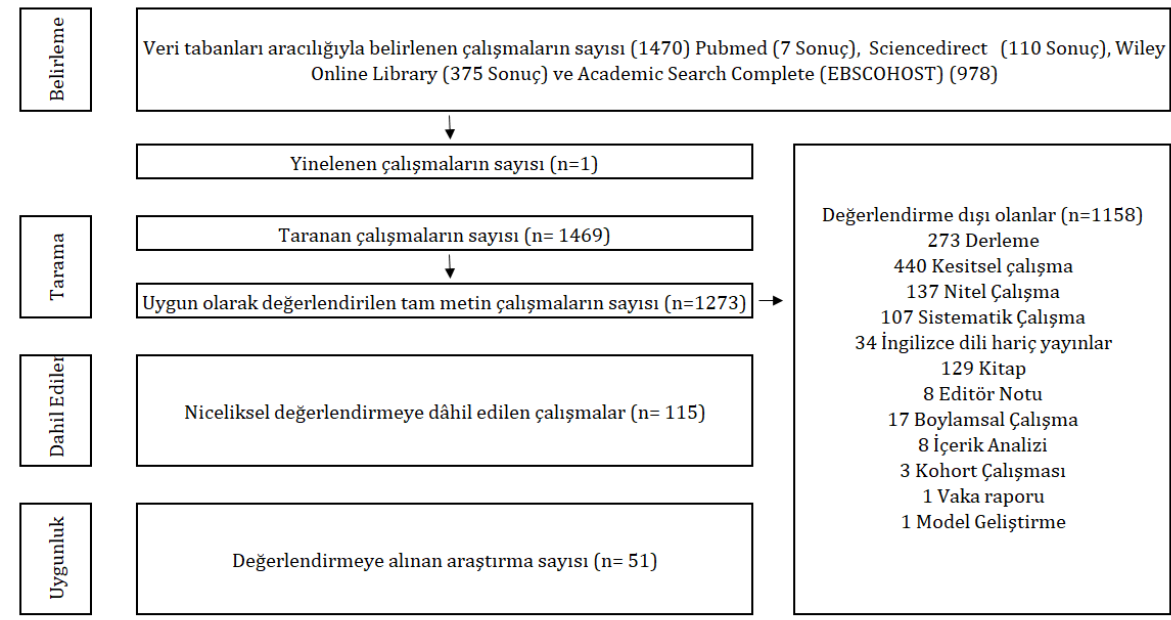

Şekil 1. PRISMA karar kriteri 


\section{Dahil Edilme ve Dışlama Kriterleri}

\section{Çalışma kapsamına dâhil edilen makalelerin seçiminde kriterleri}

1. İlkokul, ortaokul ve lise düzeyinde olmak üzere okullarda yapılan akran zorbalığını önleme çalışmaları, yapılan çalışmanın deneysel veya yarı deneysel türde olması

2. Tam metine ulaşılmış olması, eğitim programının okulda uygulanması ve okul tabanlı eğitim programı olması, yayın dilinin İngilizce olması

3. Araştırma sorusu katılımcıları (P:population), müdahaleleri (I:interventions), karşılaştırma gruplarını (C:comparators), sonuçları (0:outcomes) ve araştırma desenleri (S:study designs) olan (PICOS) basamaklarını sağlıyor olması

\section{Dışlanma kriterleri}

1. Şekil 1'de değerlendirme dışında ifade edilen çalışmalar

\section{BULGULAR}

Ekte sunulan Tablo 1'de değerlendirmeye alınan 51 araştırmanın amaç, örneklem özellikleri, uygulanan girişimler başlıklarında bulgularının özeti yer almaktadır.

\section{Amaç Bilgileri}

Derleme kapsmaında yer alan çalışmaların amaçları anaokulu, ilkokul, ortaokul ve lise gibi araştırmanın yürütüldüğü yerlere temelinde sunulmuştur. Anaokulu öğrencilerinde yürütülen müdahale çalışmalarında, Muratori ve arkadaşları (2017). İtalya'nın iki anaokulunda zorbalık davranışını önlemeye yönelik eğitim müdahalesinin, Akcan ve Ergun (2019) agresif davranış önleme programının anaokulu öğrencileri üzerindeki etkisini incelediği görülmektedir.

Yapılan derlemede ilkokul öğrencilerine yönelik çalışmalarda; Midgett ve Doumas (2016) ilkokullarda zorbalık davranışını önlemek için uygulanan pilot çalışmanın etkinliğini, Miyazaki ve arkadaşları (2016). ilkokullarda uygulanan müdahale programının zorbalık davranışına etkisini, Gaete ve arkadaşları (2017). ilkokul 4. ve 5.sınıf öğrencileri üzerinde KIVA eğitim programının etkinliğini, Newgent ve arkadaşları (2016). zorbalık türleri, kurbanları ve problemli davranış arasındaki ilișkiyi, Wang ve Goldberg (2017) The Bullying Literature ProjectMoral Disengagement Version (BLP-MD) eğitim programının etkinliğini, Farmer ve arkadaşları (2017). ilkokul oyun alanlarında artan risk ve zorlukların çocuklar arasındaki etkileşimleri etkileyip etkilemediğini, Grassetti ve arkadaşları (2018). zorbalık olayları sırasında bakıcıların tavsiyesi ve çocukların seyirci davranışlarını, Yokoo ve arkadaşları (2018). ilkokul öğrencilerine video tabanlı zorbalık davranışını önlemek amacıyla verilen eğitimin etkisini, Saınıo ve arkadaşları (2020). KIVA eğitim programının 2010-2016 yılları arasında uzun vadede etkinliğini, 
Karataş ve Öztürk (2020) ilkokullarda zorbalığa karşı geliştirilen bir programın etkisini, Clarkson ve arkadaşları (2019). İngiltere'de KIVA eğitim programının etkisini, Van Niejenhuisi ve arkadaşları (2020). ebeveyn-okul-iş birliği sağlanarak zorbalık davranışını önlemek için KIVA eğitim programının etkisini incelenmiştir.

İlkokul ve ortaokul öğrencilerine yönelik çalışmalar incelendiğinde; Clarkson ve arkadaşlarının (2016). çalışmasında ilkokul ve ortaokullarda KIVA eğitim programının zorbalık davranışına etkisini, Healy ve Sanders (2017) akranları tarafında mağduriyete maruz kalan çocukların depresyonlarını aile desteği ile tedavi edilmesini, Cipra ve Hall (2019) zorbalık davranışının önlenmesi için "CORE Matters" isimli eğitim programının etkisini, Huitsing ve arkadaşları (2019). ilkokul ve ortaokullarda KiVA eğitim programının etkinliğini, Olweus ve arkadaşları (2020). OLWEUS eğitim programının uzun yıllara olan etkisini inceleyen araştırmalar yapmışlardır.

Ortaokul öğrenci grubunda yürütülen çalışmalarda; Cross ve arkadaşları (2016). okul tabanlı hazırlanan The Cyber Friendly Schools (CFS) eğitim programının siber zorbalık davranışına etkisini, Olatunbos (2016) yaptığı çalışmada Olweus eğitim programının zorbalık davranışı üzerinde etkisini, Gregory ve arkadaşları (2016). geliştirilen "My Teaching Partner Secondary (MTP-S)” programın zorbalık davranışı üzerinde etkisini, Albayrak arkadaşları (2016). özel olarak geliştirilen Okul Zorbalık Önleme Programı'nın zorbalık davranışını önlemesini, Bonell ve arkadaşları (2017). INCLUSIVE eğitim programının zorbalık davranışına etkisini, Avşar ve Ayaz Alkaya (2017) okul çağındaki çocuklara yönelik geliştirilen bir eğitimin akran zorbalığı ve girişkenlik üzerindeki etkinliğini, Midgett ve arkadaşları (2018). okullarda zorbalığı azaltmak için STAC programının etkisini, Rana ve arkadaşları (2018). Kuzey Hindistan, Chandigarh'daki ergenler arasında zorbalığı azaltmak için çok bileșenli okul tabanlı bir müdahalenin etkinliğini, Hie Song ve arkadaşları (2018). ortaokul öğretmenlerine yönelik zorbalık davranışına karşı pasif ve aktif yapan bireysel ve çevresel faktörlere ilişkin verilen dersin etkisini, Costantino ve arkadaşları (2019). İtalya’nın bir şehrinde ortaokullarda zorbalığı azaltmaya yönelik uygulanan eğitim programının etkisini, Bowes ve arkadaşları (2019). Endonezya'da okul zorbalık davranışını önlemek için geliştirilen eğitim programının pilot çalışmasının etkisini, Federici ve arkadaşları (2019). Norveç'te 5.6.7.sınıf öğrencilerde okul hemşiresinin zorbalık davranışını azaltmada etkisini, Gouveia ve arkadaşları (2019). "The Student and Family Office (SFO)” modelinin zorbalık davranışı üzerindeki etkisini, Van Ryzin ve Roseth (2019) çalışmasında ortaokullarda işbirlikçi öğrenme yönteminin zorbalık davranışı üzerinde etkisini, Wójcik ve Hełka (2019) The ABBL eğitim programının etkinliğini, HormazábalAguayo ve arkadaşları (2019). "The Active-Start" dezavantajlı gruplar arasında zorbalık davranışı etkisini değerlendirmiştir. 
Lise öğrencilerine yönelik müdahale çalışmalarında; Barkoukis ve arkadaşları (2016). 16-18 yaş arası adölesanlarda siber zorbalığı önlemek için geliştirilen okul tabanlı eğitim programının zorbalık davranışına etkisini, Timmons-Mitchell ve arkadaşları (2016). Stand Up eğitim programının siber zorbalık davranışı üzerinde etkisini, Palladino ve arkadaşları (2016). “NoTrap!” eğitim programının siber zorbalık davranışını önlemede etkinliğini, Naidoo ve arkadaşları (2016). okullarda sözlü zorbalığı azaltmak için okul temelli bir eğitim müdahalesinin etkisini, Vives-Cases ve arkadaşları (2019). ergenlerin akranlarıyla olumlu ilişkiler geliştirmeye yönelik güçlü yönlerine ve yeteneklerine odaklanan eğitim programının etkisini, Doumas ve arkadaşları (2019). zorbalık davranışının önlenmesi için "STAC program" eğitim programının etkisini, Zambuto ve arkadaşları (2019). “NoTrap!” eğitim programı akran eğitiminde zorbalık davranışı üzerinde etkisini, Ye ve arkadaşları (2020). Video Tabanlı DT - SVM Okul Şiddeti Algılama Algoritma Eğitim programının akran eğitimi zorbalık davranışını üzerindeki etkinliğini, Shinde ve arkadaşları (2020). Hindistan'da okullarda zorbalık davranışını önlemek amacıyla "SEHER" eğitim programının etkinliğini, Fischer ve Bilz (2019) öğretmenlerin zorbalık müdahalelerinde öz-yeterlikleri ve müdahale olasılıkları değerlendirmiştir.

Yapılan derlemede üniversite ve mezun öğrencilere yönelik çalışmalar incelendiğinde; Doane ve arkadaşları (2016). çalışmasında bir üniversitede 18-23 yaşlarından oluşan öğrencilere Theory of Reasoned Action (TRA)-Video tabanlı siber zorbalık önleme programının etkinliği, Ortiz-Bush ve Schultz (2016) mini bir konferansla üniversite mezunu 13 kişiye zorbalık davranışı önlemek amacıyla video konferans yoluyla yeni geliştirilen iki günlük bir eğitim programının etkisi, Doğan ve arkadaşları (2017). VISC eğitim programının etkinliğini, Klippel ve arkadaşları (2018). “The Digital Social Peer Evaluation Experiment (Digi-SPEE)” eğitim programının akran değerlendirmesinde ergenlerin zorbalık davranışı üzerinde etkisi incelenmiştir.

Bu yapılan çalışmaların dışında Salmeron ve Christian'nın (2016) çalışmasında okul sağlığı hemşireleri ve sağlık asistanı için geliştirilmiş eğitim programının retrospektif olarak etkinliği, Rex ve arkadaşları (2018). Otizm Spektrum Bozukluğu olan 6(altı) çocuğa uygulanan ve onların zorbalık davranıșını azaltmak amacıyla verilen eğitimin etkisi incelenmiştir (Tablo 1 ekte sunulmuştur).

\section{Örneklem Özellikleri}

Derlenen araştırmalarda, örneklem kapsamına alınan gruplar farklılık göstermektedir. Çalışmaların 2'sinin anaokul öğrencileri (Akcan ve Ergun, 2019), 12'isinin ilkokul öğrencileri (Clarkson vd., 2016) gibi, 5’inin ilkokul ve ortaokul öğrencileri (Clarkson vd., 2016) gibi, 16'sının ortaokul öğrencileri (Cross vd., 2016) gibi, 10'unun lise öğrencileri (Barkoukis vd., 2016) gibi, 4'ünün üniversite öğrencileri (Doane vd., 2016) gibi, 1'inin okul sağlığı hemşireleri 
(Salmeron ve Christian, 2016) ve otizm spektrumlu bozukluğu olan çocuklardan (Rex vd. 2018) oluşan örneklem gruplarında yürütüldügü belirlenmiştir (Tablo 1 ekte sunulmuştur).

\section{Uygulanan Girişimler}

Derlenen çalışmalarda uygulanan girişimlerin, araştırmanın hedef kitlesinin özelliğine göre değiştiği belirlenmiştir. Bu çalışmalarda, video (Ortiz-Bush ve Schultz, 2016), poster (Barkoukis vd., 2016), belirli bir süre uygulanan eğitim müfredatı (Midgett ve Doumas, 2016; Cross vd., 2016), video-konferans (Van Ryzin ve Roseth, 2019), grup görüşmeleri (Grassetti vd., 2018), grup çalışmaları (Muratori vd., 2017; Farmer vd., 2017) ve hedef kitleye özel (Healy ve Sanders, 2017) olarak geliştirilmiş KIVA, OLWEUS, STAC gibi girişimler uygulanmaktadır (Huitsing vd., 2019; Olweus vd., 2020; Midgett vd., 2018) (Tablo 1 ekte sunulmuştur). Öğrencilere yönelik girişimlerde öz-saygı (Huitsing vd., 2019), öz-yeterlilik becerisini geliştirme (Fischer ve Bilz, 2019), empati (Doane vd., 2016), zorbalık davranışını önleme (Cross vd., 2016) gibi davranış geliştirmeye yönelik girişimler amaçlanmıştır. Öğretmenlere yönelik girişimlerde farkındalık (Wo'jcik ve Hełka, 2019), zorbalık davranışına müdahale etme ve ailelerle iş birliği içerisinde (Van Niejenhuisi vd., 2020) olamaya yönelik girişimler hedeflenmiştir. Ailelere yönelik girişimlerde öğrencilere sosyal destek olmaları ve okul-aile iş birliğini geliştirmeye (Grassetti vd., 2018) odaklanılmıştır.

\section{TARTIŞMA, SONUÇ VE ÖNERİLER}

$\mathrm{Bu}$ sistematik derlemede, öğrencilerde akran zorbalığı davranışını önlemeye yönelik okul temelli eğitim programlarının etkililiğini değerlendirmek üzere yapılmış deneysel ve yarı deneysel araştırmaların sonuçları incelenmiştir. Yarı deneysel çalışmalarda, genellikle STAC, Theory of Reasoned Action (TRA)-Video tabanl, The Student and Family Office (SFO), No Trap, Video Tabanlı DT - SVM, OLWEUS, KIVA isimli özel olarak tasarlanmış eğitim programları kullanılmıştır. Bu programalar genellikle öğrenci merkezli ve kısa süreli olarak hazırlanmış programlardır. Randomize Kontrollü Çalışmalar, yarı-deneysel çalışmalar gibi The Cyber Friendly Schools (CFS), KIVA, My Teaching Partner Secondary (MTP-S), No Trap, CORE, Matters, STAC, Then Active-Start, The ABBL, SEHER ve Oyun alanlarına yönelik tasarlanmış programlar olmakla birlikte KIVA eğitim programı sıklıkla kullanılmıştır. Araştırmada randomize kontrollü çalışmalar; uzun süreli, örneklem büyüklüğü diğer çalışmalara kıyasla çok fazla ve öğrencilerde beceri geliştirme üzerine yoğunlaşıldığı tespit edilmiştir. Sistematik derleme kapsamındaki araştırmalar anaokul, ortaokul, lise ve üniversite gibi araştırmanın yürütüldügü yer üzerinden elde edilen bulgulara göre tartışılmıştır.

Yapılan sistematik derlemede ana okul öğrencileri ile yapılan önleme çalışmaları değerlendirildiğinde, Muratori ve arkadaşları (2017). yaptığı çalışmada, zorbalık davranışını 
önlemek için yapılan girişimle anaokulu öğrencilerinin öğretmenlere ve ebeveynlerine karşı zorbalık davranışlarında azalma olduğu tespit edilmiştir. Çalışmanın anaokul öğrencilerinde hem öğretmenlere hem de ebeveynlere karşı zorbalık davranışının azaltılması için rehberlik edebileceği düşünülmüştür. $\mathrm{Bu}$ çalışmanın bulgularını destekler bir sonuç Anticich ve arkadaşları (2013). tarafından yürütülen araştırmadan da elde edilmiştir (Anticich vd., 2013). Akcan ve Ergun (2019) anaokulu öğrencileri üzerinde agresif davranışları önlemek için yaptığı çalışma sonucunda öğrencilerin saldırganlık düzeylerinin önemli ölçüde azaldığı tespit edilmiştir. $\mathrm{Bu}$ çalışma Türkiye'de okulda çalışan bir hemşire tarafından yapılan ilk çalışmalardandır ve halk sağlığı hemşirelerine uygulama ve araştırmada örnek olması açısından önem arz etmektedir. Literatürde bu çalışmayı ana okulu öğrencileri üzerinde zorbalık davranışını azaltan çalışma olması yönünden destekleyen çalışma bulunmaktadır (Diamond, vd., 2019).

Yapılan sistematik derlemede ilkokul öğrencileri ile yapılan önleme çalışmaları değerlendirildiğinde, Midgett ve Doumas (2016) 4. ve 6. sınıf öğrencilerinde STAC eğitim programının zorbalık davranışı üzerinde etkinliği incelenmiş ve zorbalık davranışını azaltmada etkili olduğu tespit edilmiştir. Literatürde STAC eğitim programının zorbalık davranışını önlemede etkin olduğu mevcuttur ve kullanılan STAC eğitim programı yönünden destekleyen çalışmalar bulunmaktadır (Midgett vd., 2021). Gaete ve arkadaşları (2017). ilkokullarda KIVA eğitim programını, Clarkson ve arkadaşları (2019). İngiltere'de 41 ilkokulda uygulanan KIVA eğitim programının etkinliğini ve maliyet açısından önemini vurgulamış, Saınıo ve arkadaşları (2020). ilkokullarda KiVA eğitim programını, Van Niejenhuis ve arkadaşları (2020). ilkokullarda KIVA eğitim programını zorbalık davranışının önlenmesi için okullarda uygulanmıştır. Yapılan tüm uygulamalarda KIVA eğitim programının başarılı olduğu tespit edilmiştir. Bu sistematik derlemede tespit edilen KIVA eğitim programları genellikle öğrencilere yönelik uygulanırken Van Niejenhuis ve arkadaşları (2020). yaptığı çalışmada, zorbalık davranışını önlemek için ebeveyn-okul iş birliğini dikkat çekmekte ve zorbalığı önlemede ebeveyn-okul iş birliğini sistematik olarak ortaya koyan ilk çalışmadır. Bu bağlamda literatürde Van Niejenhuis ve arkadaşları (2020). yaptığı çalışmayı destekleyen çalışmalar bulunmaktadır (Mann vd., 2015). Miyazaki ve arkadaşları (2016). yaptığı çalışmada ilkokullarda uygulanan müdahale programının erkeklerde zorbalık davranıșı üzerinde bir değișim olmadığını ve kızlarda anlamlı bir fark olduğunu tespit etmiştir. Literatürde birçok çalışma erkeklerin, kızlara göre zorbalık davranışına daha meyilli olduğunu açıklamaktadır (Fisher vd., 2018; Olweus, 1994). Newgent ve arkadaşları (2016). yaptığı çalışmada ilkokul öğrencilerine öğretmenleri tarafından zorbalık davranışını önleme eğitimi verilmiştir ve bütün zorbalık türlerinde azalış olduğu tespit edilmiştir. Literatürde öğretmenler tarafından uygulanan zorbalık önleme eğitim programının etkin olduğunu belirten çalışma olması yönünden destekleyen çalışmalar mevcuttur (Espelage 
vd., 2013). Wang ve Golberg (2017) yaptığı çalışmada The Bullying Project-Moral Disengagement Version (BLP-MD) eğitim programının 3. sınıf öğrencilerine uygulanmıştır. Çalışma sonunda akranların birbirlerini dahi tanıdığı ve öğretmenler tarafından sosyal geçerliliği olan bir program olarak değerlendirilmiştir. Fakat literatürde uygulanan eğitim programı hakkında bir çalışmaya rastlanmamıştır. Bundan dolayı uygulanan eğitim programı hakkında daha çok çalışmalara ihtiyaç bulunmaktadır.

Farmer ve arkadaşları (2017). yaptığı çalışmada ilkokul öğrencilerinin oyun alanlarında artan risk ve zorbalık davranışının çocuklar arasındaki etkileşimleri incelemiştir. Çalışma sonunda ilkokul öğrencilerinde müdahale grubu, kontrol grubuna göre daha mutlu, daha az zorbalık davranışına maruz kaldığı tespit edilirken çocuklarının zorbalık davranışına maruz kalma durumunu bildirme/bildirmemesinde anlamlı bir fark tespit edilmemiştir. Ayrıca müdahale grubundaki öğretmenler 1 yıl içinde daha fazla zorbalık davranışı tespit etmiştir ve ebeveynler bu çalışmayı desteklemektir. Bu çalışma okul-aile-öğrenci merkezli yapıldığı için önem arz etmektedir ve literatürde destekleyen çalışmalar mevcuttur (Van Niejenhuisi vd., 2020). Yapılan çalışmada öğrencilerin zorbalık davranışına maruz kalma durumunu bildirme/bildirmemesinde anlamlı bir fark tespit edilmemesi öğrencilerin, kendilerinde okul ortamında güvenli hissetmemesi veya öğretmenlere olan güven eksikliğinden kaynaklanabilir. Grassetti ve arkadaşları (2018). çalışmasında bakıcıların öğrencilere verdikleri tavsiyelerin zorbalık davranışına etkisini araştırmıştır. Yapılan araştırmada okul-aile iş birliğine dikkat çekilmiştir. Literatürde konu ile ilgili olarak destekleyen çalışmalar bulunmaktadır (Van Niejenhuisi vd., 2020). Yokoo ve arkadaşları (2018). yaptığı çalışmada sadece video tabanlı bir çalışmadır. Bu çalışmada ilkokul öğrencilerinin bilgi düzeyinin arttığı fakat sürdürülebilir bir program geliştirilmesi tavsiye edilmiştir. Literatürde yapılan çalışmayı destekler nitelikte çalışmalara bulunmaktadır (Ye, vd., 2020).

Karataş ve Öztürk (2020) yaptığı çalışma sosyal bilişsel teori kullanarak ilkokul öğrencilerinde zorbalık davranışının azaltılması amaçlandığı çalışmada öğrencilerde zorbalık davranışı azalmış ve sosyal bilişsel teorinin etkin olduğu tespit edilmiştir. Literatürde hemşirelerin okul sağlığında zorbalık davranışını önlemede etkin olduğuna gösteren birçok çalışma mevcuttur (Akcan ve Ergun, 2019; McFarlane, 2017). Bu bağlamda Karataş ve Öztürk (2020) yaptığı çalışmada sosyal bilişsel teorisini kullanması dikkat çekicidir. Bundan dolayı hemşirelerin model tabanlı zorbalık davranışını önlenmesini sağlayan çalışmalara ihtiyaç bulunmaktadır

Yapılan sistematik derlemede ilkokul ve ortaokul öğrencileri ile yapılan önleme çalışmalarının değerlendirildiğinde, Clarkson ve arkadaşları (2016). ilkokul ve ortaokullarda KIVA eğitim programının etkisini incelemiştir. Literatürde uygulanan KiVA eğitim programını 
destekler nitelikte çalışmalar mevcuttur (Gaete vd., 2017; Clarkson vd., 2019). Healy ve Sanders (2017) yaptığı çalışmada yüksek depresyonda olan 6-12 yaşları arasındaki 39 çocuğa zorbalık davranışını önlemek için eğitim programı uygulanmıştır. Yapılan çalışma sonucunda 26 öğrencinin tedavi edildiği ve 13 öğrencide depresyonun devam ettiği tespit edilmiş ve bu çalışma öğrencilerde zorbalık davranışı sonucunda depresyonun oluşması açısında dikkat çekicidir. Ayrıca bu çalışmada aile ve akran desteğinin tedavide etkili olduğu belirtilmiştir. Literatürde zorbalık davranışı sonucunda depresyon oluştuğunu belirten çalışmalar mevcuttur ve yapılan çalışmayı destekler niteliktedir (Olweus, 1994). Ayrıca aile ve akran desteğinin önemli olduğunu belirten çalışmayı destekler nitelikte literatürde çalışma mevcuttur (Biswas vd., 2020) ve literatürde zorbalık davranışını önlemede aile ve akran desteğinin önemsiz olduğuna dair çalıșmaya rastlanmamıștır. Yapılan çalıșma sonucunda zorbalık davranıșını önlemek için aile-akran desteğinin önemli olduğu ortaya çıkmakta ve yapılacak olan çalışmalara rehberlik edebilir. Cipra ve Hall (2019) yaptığı çalışmada CORE Matters eğitim programının ortaokullarda zorbalık davranışı üzerinde etkinliği araştırılmıștır. Yapılan çalışma sonucunda öğrencilerde öz-güven, okula uyum faktörlerinde anlamlı farklılıklar tespit edilmiş ve öğrencilerde okul öğretmenleri ve yöneticileri hakkında olumlu görüş oluştuğu tespit edilmiştir. Literatürde CORE Matters eğitim programını destekleyen çalışmaya rastlanmamıştır. Huitsing ve arkadaşları (2019). KIVA eğitim programını uygulamıştır. Literatürde KIVA eğitim programını başarılı olduğunu belirten çalışmalar mevcuttur (Clarkson vd., 2019; Gaete vd., 2017; Saınıo vd., 2020). Olweus ve arkadaşları (2020). OLWEUS eğitim programının etkinliğini incelemiş ve uygulanan eğitim programı zorbalığı azaltmada etkili olduğu bulunmuştur. Olweus ve arkadaşları (2020). yaptığı çalışma 1.ve 7.sınıf öğrencileri üzerinde uzun vadede gerçekleştiği için dikkat çekicidir. Literatürde, bu iki çalışmayı destekleyen çalışmalar bulunmaktadır (Farrell vd., 2018).

Cross ve arkadaşları (2016). ortaokullarda siber zorbalık davranışını önlemek için uyguladıkları eğitim programının öğrencilerde siber zorbalığı azalttığı tespit edilmiştir. Ayrıca siber zorbalık hakkında yapılan çalıșmaların hepsinde öğrencilerde bilgi düzeyinde artış, empati gelişimi, olumlu sosyal beceri gelişimi oluştuğu tespit edilmiştir. Bu araştırma sonuçları literatürde siber zorbalığı önlemek için yapılan çalışmalarla uyumlu olduğu tespit edilmiştir (Hutson vd., 2018). Olatunbosun (2016) ortaokul OLWEUS eğitim programının etkinliğini incelemiş ve uygulanan eğitim programı zorbalığı azaltmada etkili olduğu bulunmuştur. Literatürde, bu çalışmayı OLWEUS eğitim programının etkinliği yönünden destekleyen çalışmalar bulunmaktadır (Farrell vd., 2018). Gregory ve arkadaşları (2016). yaptığı çalışmada "My Teaching Partner Secondary (MTP-S)" eğitim programı öğretmenlerin, öğrencilere koçluk yaparak zorbalık davranışı üzerindeki etkisi incelenmiştir. Çalışma sonucunda irksal zorbalık üzerinde etkili olduğu tespit edilmiş ve siyah ırka sahip olan öğrenciler, siyah olmayan 
öğrenciler arasında anlamlı bir fark oluşmuştur. Literatürde bu çalışmayı My Teaching Partner Secondary (MTP-S) eğitim programını yönünden destekleyen çalışmalar mevcuttur (Allen vd., 2015). Albayrak ve arkadaşları (2016). ortaokullarda zorbalık davranışı azaltmak için 3 aylık eğitim vermiştir. Eğitim sonrası mağdur öğrencilerin \%32.1'i durumu kimseye söylemedikleri, mağdur olan çocukların \%37.2'si bir arkadaşına anlattığı, \%30.1'i ebeveynlerine açıkladığı ve \%12.1'inin durumu sınıf öğretmenlerine açıkladıkları tespit edilmiştir. Ayrıca öğrenciler zorbalığı, öğretmen sınıfta yokken, koridorda, tuvalette ve okul bahçesinde maruz kaldıklarını belirtmiştir. Albayrak ve arkadaşları (2016). yaptığı çalışmada Neuman sistemler modelini kullanması dikkat çekicidir. Bu çalışma sağlığın, korunması, geliştirilmesi ve sürdürülmesi açısından halk sağlığı hemşirelerine moodel tabanlı zorbalık davranışını önlenmede rehberlik edebilir. Literatürde yapılan çalışmayı Neuman sistemeler modeli ile destekleyen çalışma bulunmaktadır (Evgin ve Bayat, 2020).

Bonell ve arkadaşları (2017). yaptığı çalışmada sosyal ve duygusal eğitim programı çerçevesinde hazırlanmış INCLUSIVE Eğitim programının zorbalık davranışına etkisini incelemiştir. Yapılan çalışma ortaokullarda 3 yıl uygulanmış ve yapılan çalışmada öğrencilerde zorbalık davranışlarının azaldığı tespit edilmiştir. Literatürde INCLUSIVE Eğitim programının zorbalık davranışını önlemede etkili olduğunu belirten çalışmalar mevcuttur ve yapılan çalışmayı destekler niteliktedir (Bonell, 2018). Avşar ve Ayaz Alkaya (2017) ilkokul 5. ve 6. sınıf öğrencileri üzerinde yaptığı çalışmada sonucunda girişkenlik eğitimi programının öğrencilerde atılganlık düzeyini artırdığı ve mağdur olma durumunu azalttığı, ancak zorba olma durumunu etkilemediği tespit edilmiştir. Literatürde hemşirelerin okul sağlığında zorbalık davranışını önlemede etkin olduğuna gösteren birçok çalışma mevcuttur (Akcan ve Ergun, 2019; McFarlane, 2017). Zorbalık davranışını önlemede öğretmenlerin yeteneklerinin önemli olduğuna ve zorbalık davranışını önlemede aktif rol alabileceği vurgulanmaktadır (Christian Elledge vd., 2013). Hie Song ve arkadaşları (2018). çalışmasında öğretmenlerin zorbalık davranıșına karşı müdahale etmelerinde, pasif ve aktif olarak etki eden çevresel faktörlerin önemini ifade etmiştir.

Midgett ve arkadaşları (2018). ortaokul öğrencilerinde STAC eğitim programının zorbalık davranışı üzerinde etkinliği incelenmiş ve zorbalık davranışını azaltmada etkili olduğu tespit edilmiştir. Literatürde, yapılan çalışmayı STAC eğitim programının etkinliği yönünden destekleyen çalışmalar bulunmaktadır (Midgett vd., 2021). Rana ve arkadaşları (2018). ortaokul öğrencilerinde üzerinde yapılan çalışmada öğrencilerin zorbalık davranışında, öğretmenlere ve ebeveynlerine karşı zorbalık davranışlarında azalış olduğu tespit edilmiştir. Bu çalışma hem öğretmenlere hem de ebeveynlere karşı zorbalık davranışının azaltılmasında rehberlik edebilir. Literatürde bu çalışmayı ebeveynlere ve öğretmenlere karşı uygulanan zorbalık davranışını azalttığını destekler nitelikte çalışmaya rastlanmıştır (Muratori vd., 2017). 
Costantino ve arkadaşları (2019). ortaokul öğrencilerinde yapılan çalışmada zorbalığın bütün türlerinde azalma olduğu tespit edilmiştir. Özellikle orta sosyoekonomik düzeydeki okullara devam eden öğrencilerde zorbalık davranışının anlamlı derecede azalma olması dikkat çekicidir. Literatürde bu çalışmayı sosyoekonomik düzeydeki düşük ve orta gelirli ülkelerde zorbalık davranışını azaltması yönünden destekleyen çalışma bulunmaktadır (Rana vd., 2018). Bowes ve arkadaşları (2019). Endonezya'da yaptığı çalışmada öğrenci ve öğretmenlerin zorbalık davranışlarına karşı öz- yeterliliklerinin artırılması amaçlanmıştır. Yapılan çalışma sonucunda Roots Eğitim programı kabul edilebilir ve uygulanabilir olduğu test edilmiştir. Fakat çalışma sonucunda programın etkililiğini ve maliyet etkinliğini incelemek için birçok çalışmaya ihtiyaç olduğu vurgulanmıștır. Literatürde yapılan çalışmayı Roots Eğitim programı yönünden destekler nitelikte çalışma bulunmaktadır (Santos vd., 2011). Federici ve arkadaşları (2019). Norveç'te 5.6.7. sınıf öğrencilerde okul hemşiresinin zorbalık davranışını azaltmada etkisini incelemiş ve yapılan çalışma sonucunda öğrencilerin akademik performansı, okula uyum hali, okula aidiyet duygusu, öğrencilerin derse katılımı, benlik kavramı, motivasyon ve okula devamsızlığı azalttığına dair önemli sonuçları olduğu tespit edilmiştir. Bu çalışma halk sağlığı hemşirelerine rehberlik edebilir. Literatürde hemşirelerin okul sağlığında zorbalık davranışını önlemede etkin olduğuna gösteren çalışma mevcuttur (McFarlane, 2017). Gouveia ve arkadaşları (2019). yaptığı çalışmada ortaokul öğrencilerinde The Student and Family Office (SFO) eğitim programının zorbalık davranışı üzerinde etkisi incelenmiştir. Çalışma sonunda öğrencilerde saldırganlık ve mağduriyet azalmış ve kişilerarası ilişkiler ve sosyal beceri düzeyleri artmıștır. Literatürde The Student and Family Office (SFO) eğitim programı hakkında başka bir çalışmaya rastlanmamıştır. $\mathrm{Bu}$ bağlamda The Student and Family Office (SFO) eğitim programı hakkında daha çok çalışmalara ihtiyaç bulunmaktadır.

Van Ryzin ve Roseth (2019) yaptığı çalışmada toplam 2 yıl olmak üzere hafta 1,5 gün ortaokul öğrencilerine Video-konferans ile eğitim verilmiş zorbalık davranışı azaldığı ve olumlu davranışların geliştiği tespit edilmiştir. Literatürde bu çalışmayı destekleyen çalışma bulunmaktadır (Ortiz-Bush ve Schultz, 2016). Wójcik ve Hełka (2019) yaptığı çalışmada öğretmenler tarafından uygulanan The ABBL eğitim programının ortaokul öğrencilerinin zorbalık davranışı üzerinde etkisi araştırılmış ve zorbalık davranışı azaldığı tespit edilmiştir. Literatürde The ABBL eğitim programı ile ilgili başka bir çalışmaya rastlanmamıştır. $\mathrm{Bu}$ doğrultuda programın etkinliği başka öğrencilerde test edilmelidir. Ayrıca bu program öğretmenler tarafından uygulandığı için zorbalık davranışını azaltmada öğretmenlerin etkili rol alabileceğini göstermektedir. Hormazábal-Aguayo ve arkadaşları (2019). yaptığı çalışmada okul öncesi dezavantajlı gruplar arasında oyun temelli fiziksel aktivite eğitim programı ile zorbalık davranışının azaltılması amaçlanmıştır. Çalışma sonunda öğrencilerde sözel ve fiziksel 
zorbalığın azaldığı tespit edilmiştir. Literatürde okul öncesi öğrencilerde yapılan bir çalışma bulunmaktadır ve yapılan çalışmayı destekler niteliktedir (Akcan ve Ergun, 2019).

Yapılan sistematik derlemede lise öğrencileri ile yapılan zorbalık önleme çalışmaları değerlendirildiğinde, Barkoukis ve arkadaşları (2016). ve Palladino ve arkadaşları (2016). liselerde siber zorbalığı, Zambuto ve arkadaşları (2019). liselerde genel zorbalık ve siber zorbalık davranışını önlemek için çalışmalar yapmıştır. Yapılan çalışmalarda uygulanan eğitim programları öğrencilerde siber zorbalığı azalttığı tespit edilmiştir. Ayrıca siber zorbalık hakkında yapılan çalışmaların hepsinde öğrencilerde bilgi düzeyinde artış, empati gelişimi, olumlu sosyal beceri gelişimi oluştuğu tespit edilmiştir. $\mathrm{Bu}$ araştırma sonuçları literatürde siber zorbalığı önlemek için yapılan çalışmalarla uyumlu olduğu tespit edilmiştir (Hutson vd., 2018). Timmons-Mitchell ve arkadaşları (2016). yaptığı çalışmada Stand Up eğitim programının liseli öğrencilerde zorbalık davranışı üzerinde etkinliğini incelemiştir. Yapılan çalışmada duygusal ve fiziksel zorbalığın azaldığı ve seyirci olarak katılan akranlarda da duygusal ve fiziksel zorbalıkta azalış olduğu tespit edilmiştir. Literatürde Stand Up eğitim programını destekleyen çalışmalara rastlanmamıştır. Naidoo ve arkadaşları (2016). yaptığı çalışmada liseli öğrencilerde kızların sözlü zorbalığa maruz kalma olasılığı daha yüksek, babası yaşamayan ve annesi olmayanlar başkalarına sözlü zorbalık yapma olasılığı daha yüksek bulunmuştur. Literatürde sözlü zorbalık türünün kızlarda yüksek olduğuna dair çalışmalar bulunmaktadır (Olweus,1994) fakat sadece sözlü zorbalık türüne odaklanan çalışmalara rastlanmamıştır. Ayrıca bu çalışma sözlü zorbalık ile aile durumu ilişkisini ortaya çıkarması yönünden önem arz etmektedir. Vives-Cases ve arkadaşları (2019). yaptığı çalışmada, ergenlerin akranlarıyla olumlu ilişkiler geliştirme ve flört ilişkisi şiddetini önlemeye yönelik ilk uluslararası çalışmadır. Yapılan çalışmada İspanya, İtalya, Romanya, İngiltere, Polanya, Porekiz, olmak üzere altı Avrupa ülkesinde orta öğretim okullarına kayıtlı 13-17 yaşları arasındaki erkek ve kızlarda yapılmıştır. Çalışma sonucunda programın gençlerin sağlıklarını ve iyilik hallerini geliştirmek için bir araç olarak kullanılması uygun bulunmuştur. Literatürde zorbalık hakkında uluslarası çalışma olmakla birlikte (Barzilay, 2017) fakat yapılan çalışmayı destekleyen uluslararası çalışmaya rastlanmamıştır. Bundan dolayı bu çalışma önem arz etmektedir. Doumas ve arkadaşları (2019). lise öğrencilerinde STAC eğitim programının zorbalık davranışı üzerinde etkinliği incelenmiş ve zorbalık davranışını azaltmada etkili olduğu tespit edilmiştir. Literatürde, STAC eğitim programının etkinliğini destekleyen çalışmalar bulunmaktadır (Midgett vd., 2021). Ye ve arkadaşları (2020). yaptığı çalışmada Video Tabanlı DT - SVM Okul Şiddeti Algılama Algoritma Eğitim programının zorbalık davranışı üzerinde etkisi incelenmiş ve günlük yaşam aktiviteleri ile zorbalık davranışı arasında zıt ilişki bulunmuştur ve bu programın sonucunda zorbalık davranışı azalmıştır. Literatürde bu çalışmayı destekleyen bir çalışmaya rastlanmamıştır. Fakat bu çalışma zorbalık davranışı ile günlük yaşam 
aktivitelerini ortaya çıkarması açısından önem arz etmektedir. Okullarda sağlığı geliştirilmesi, korunması ve sürdürülmesi için bu tür çalışmalara ihtiyaç bulunmaktadır.

Shinde ve arkadaşları (2020). yaptığı çalışmada SEHER eğitim programı 2 yıl süre ile liseli öğrencilere uygulanmış ve eğitim programı sonucunda okul ortamı, depresyon, cinsiyet eşitliğine karşı tutum, zorbalık sıklığı, şiddet mağduriyeti, şiddet suçu faktörlerinde anlamlılık tespit edilmiştir. Literatür incelendiğinde SEHER eğitim programının etkinliğini destekleyen bir tane çalışma bulunmaktadır ve bu çalışma yapılan çalışma ile yazarların ve ülkenin aynı olması dikkat çekicidir (Shinde vd., 2018). Bu programın etkinliği için başka ülkelerde ve farklı kişiler tarafından uygulanmalıdır. Ayrıca bu çalışmanın önemli bir noktası bu eğitim programını okullarda çalışmayan bir personel tarafından verilmiştir. Bu bağlamda okullarda zorbalık davranışını önlemek için sadece okul personeli olmaya gerek olmadığı ortaya çıkmaktadır. Fischer ve Bilz (2019) yaptığı çalışmada öz-yeterliliği yüksek olan öğretmenlerin zorbalık davranışlarını önlemede etkili olduğu ve zorbalık davranışını önlemek için öz-yeterliliklerinin artırılmasının gerekli olduğu tespit edilmiştir. Hie Song ve arkadaşları (2018). yaptığı çalışmada öğretmenleri zorbalık davranışına karşı müdahalede pasif ve aktif olarak etki eden çevresel faktörlerin önemini ifade etmiştir. Literatürde zorbalık davranışını önlemede öğretmenlerin yeteneklerinin önemli olduğuna ve zorbalık davranışını önlemede aktif rol alabileceğine dair çalışma bulunmaktadır (Christian Elledge vd., 2013).

Yapılan sistematik derlemede üniversite öğrencileri ile yapılan önleme çalışmaları değerlendirildiğinde, Doane ve arkadaşları (2016). üniversite öğrencilerinde siber zorbalığı azaltmak amaçlanmış ve uygulanan eğitim programları öğrencilerde siber zorbalığı azalttığı tespit edilmiştir. Ayrıca siber zorbalık hakkında yapılan çalışmaların hepsinde öğrencilerde bilgi düzeyinde artış, empati gelişimi, olumlu sosyal beceri gelişimi oluştuğu tespit edilmiştir. Bu araştırma sonuçları literatürde siber zorbalığı önlemek için yapılan çalışmalarla uyumlu olduğu tespit edilmiştir (Hutson vd., 2018). Ortiz-Bush ve Schultz (2016) yaptığı çalışmada 13 öğrenciye 2 günlük mini video-konferans ile eğitim verilmiş ve öğrencilerde zorbalık davranışlarının azaldığı ve olumlu davranışların geliştiği tespit edilmiştir. Literatürde bu çalışma destekleyen çalışma mevcuttur (Van Ryzin ve Roseth, 2019). Bu iki çalışma ileride video-konferans yoluyla yapılacak olan çalışmalara rehberlik edebilir. Doğan ve arkadaşları (2017). yaptığı çalışmada VISC eğitim programının mağdur kişiler ve suçlama durumu üzerinde etkili olduğu tespit edilmiş. Ayrıca bu çalışma Türkiye'de VİSC programının ilk uygulandığı çalışmadır ve sosyal politikalar için önem arz etmektedir. Literatürde VISC eğitim programına yönelik çalışmalar bulunmaktadır ve yapılan bu çalışmayı destekler niteliktedir (Gradinger vd., 2021). Bu çalışma Türkiye'de VISC eğitim programının ilk uygulaması olmasından dolayı önem arz etmektedir ve VİSC eğitim programının etkinliği için birçok çalışmaya ihtiyaç bulunmaktadır. Klippel ve 
arkadaşları (2018). yaptığı çalışmada "The Digital Social Peer Evaluation Experiment (Digi-SPEE)" eğitim programında akran değerlendirmesinde zorbalık davranışının etkisini incelemiştir. Yapılan çalışma sonucunda ergenler arasında zorbalık davranışında çevrenin etkili olduğu tespit edilmiştir. Geçmiş ve öznel sosyal durumların akran zorbalık davranışını etkilediği tespit edilmiştir. Literatürde yapılan çalışmayı destekleyen çalışmalar bulunmaktadır (Saarento vd., 2015).

Salmeron ve Christian (2016) okullarda zorbalığı önlemek için okul sağlığı hemşirelerinin ve sağlık teknisyenlerinin becerilerinin artırılması amacıyla yürüttükleri çalışmada, uygulanan programın etkili olduğunu belirlemişlerdir. Literatürde bu grup üzerinde yürütülen başka çalışmaya rastlanmamıştır. Akran zorbalığının önlenmesi, okul sağlı̆̆ı hizmetleri kapsamına giren önemli bir konudur ve bu hizmeti sunan meslek grupları üzerinde çalışmaların arttırılması yararlı olacaktır. Otizm spektrum bozukluğu olan çocuklar, akran zorbalığı davranışlarına maruz kalan özel bir gruptur (Hoover ve Kaufman, 2018). Rex ve arkadaşları (2018). otizm spektrum bozukluğu olan çocuklara karşı işlenen zorbalık davranışına otizm spektrum bozukluğu çocukların tepki vermesini öğretmek amacıyla otizm spektrum bozukluğu olan çocuklara video tabanlı verilen eğitim programının etkinliğini incelemiştir. Literatürde otizm spektrum bozukluğu olan çocuklara yönelik girişimsel çalıșmalar olmasına rağmen akran zorbalığını önlemeye yönelik bu çalışmadan başka bir araştırmaya rastlanmamıştır. Bu çalışma, otizm spektrum bozukluğu olan çocukların kendilerine uygulanan zorbalık davranışın tanımlayabilmeleri açısından sınırlı olarak yapılan çok değerli bir kaynak niteliğindedir.

Derleme kapsamında ulaşılan son beş yılda yapılmış akran zorbalığını önleme çalışmalarından ulaşılan 51 araştırmadan ancak 15'i kanıt düzeyi yüksek randomize kontrollü araştırmalardır. Araştırmada yarı deneysel araştırmalar genelde kısa süreli ve randomize kontrollü araştırmalar uzun süreli araştırmalar olarak tespit edilmiştir. Değerlendirmeye alınan araștırmalar içinde, özellikle randomize kontrollü çalıșmaların öğrencilerde zorbalık davranıșını önlemede etkili olduğu ve bu randomize kontrollü çalışmalarda özel olarak tasarlanan KIVA ve OLWEUS eğitim programlarının okul, aile ve öğrenci merkezli ve uzun vadede etkili sonuçlar elde ettiği tespit edilmiştir. Araştırmalarda özellikle ilkokul, ortaokul ve lise öğrencileri üzerine yoğunlașılmıştır. Araştırmada bazı programların davranış modeli temelli yapılması ise programların daha sistematik olarak uygulanmasına destek sağlamıştır. Araştırmada taranan veri tabanlarından dolayı dezavantajlı çalışmalara yeterince ulaşılamamıştır. Araştırmada uygulanan eğitim programları sonucunda öğrencilerde empati gelişimi, ahlaki kavramlarında ve sosyal bilişsellerinde olumlu gelişme, bilgi düzeyinde artış, öğrencilerin ırkçı yaklaşımlarında azalma, okula uyumda, öz-güvende, okula aidiyet duygusunda ve ders başarılarında, derse 
katılımında ve motivasyonda artış ve okula devamsızlıkta azalış olduğu, öğrencilerde depresif belirtilerde azalma olduğu, zorbalık türlerinin hepsinde azalma, öğrencilerin maruz kaldığı zorbalık davranışını arkadaşlarına, ebeveynlerine ve öğretmenlerine açıkladığı, öğrencilerin zorbalık davranışına genellikle öğretmen sınıfta yokken, koridorda, tuvalette ve okul bahçesinde maruz kaldığı, erkeklerin fiziksel zorbalığa ve kızların sözlü zorbalık türünü uyguladığı ve maruz kaldığı, tek ebeveynli aile yapısına sahip öğrencilerin zorbalık davranışına daha meyilli olduğu, zorbalık davranışını sergilemede çevrenin ve öğrencinin geçmişi ile ilişkisi olduğu, zorbalığı önlemek için aile ve akran desteğinin ve okul-aile-iş birliğinin önemli olduğu, zorbalığı önlemede pasif olan öğretmenlerin desteklenmesi ve aktif olanların ise teşvik edilmesi gerektiği, bazı programların düşük ve orta gelirli ülkelere rehberlik edebileceği, uygulanan bazı programların orta sosyoekonomik düzeydeki okullarda etkili olduğu, zorbalığı azaltmak için bazı uluslararası çalışmaların teşvik edildiği, Türkiye'de zorbalık davranışını önlemek için ViSC eğitim programı gibi yeni programlar üzerinde çalışıldığı sonucuna ulaşılmıştır. Araştırma zorbalığı önlemek için okul rehberlik ve psikolojik danışmanlara, psikologlara, sosyal hizmet uzmanlarına, halk sağlığı hemşirelerine rehberlik edebilir. Halk sağlığı hemşireliğinin felsefesi toplumda eșitsizlikleri önleme, sosyal adalet ve sağlığın korunması ve geliștirilmesi (Dağhan, 2017) olduğundan yapılan çalışmalarda hemşireler, eğitici, danışman ve savunucu rollerini kullanarak diğer meslek gruplarıyla iş birliği sağlayarak zorbalığın önlenmesine katkı sağlamıştır.

Amerika Birleşik Devletleri'nde 2018 yılında yayınlanan Ulusal Okul Çevre Raporu, LGBT öğrencilerin en çok cinsel kimlikleri nedeniyle sözlü zorbalığa maruz kaldığını ifade etmektedir (Kosciw vd., 2018). Akran zorbalığına ilişkin literatür incelendiğinde, doğrudan dezavantajlı gruplara yönelik sınırlı sayıda kanıta dayalı çalışmanın bulunduğu da görülmektedir (Willging vd., 2016). Bununla birlikte literatürde dezavantajlı gruplara yönelik öğretmenlere farkındalık eğitim verildiği tespit edilmiştir (Day vd., 2020). Bundan dolayı LGBT öğrencilerine yönelik müdahale çalışmalarına ihtiyaç olduğu tespit edilmiştir. Okullarda zorbalık davranışının önlenmesinde ekibin bir üyesi olan okul sağlığı hemşireleri Türkiye'de özel sektör ve yatılı yurtları olan kamu kuruluşu okullarında istihdam edilmektedir (Yıldırım vd., 2021). Zorbalık davranışı ile etkili mücadele edebilmek için gündüz eğitim veren kamu kuruluşu okullarında lisans mezunu okul sağlığı hemşireleri istihdam edilmesine ihtiyaç bulunmaktadır.

Okullarda zorbalık davranışını önlemek için ailelere, aile eğitimi ve bireysel psikolojik danışmanlık ve farkındalık eğitimi, ailelere çocuk yetiştirme tarzı, aile içi şiddet hakkında eğitim, parçalanmış aile yapısı olan öğrencilere ve ailelere farkındalık eğitimi verilmelidir. Okullarda zorbalık davranışını önlemek için öğrencilere, içinde yaşanılan çevrenin olumsuz riskleri, görsel medyanın olumsuz etkileri, bencillik-paylaşım duygusu eksikliği, bireysel gelişim sorunları, 
olumsuz kız-erkek ilişkileri hakkında farkındalık eğitimi verilmelidir. Okullarda zorbalık davranışını önlemek için okul yöneticileri, öğretmenleri bilgilendirme, öğretmenlerin konu ile ilgili beceri gelişimini teşvik etme, öğrencilere kuram temelli zorbalık önleme eğitim modeli uygulaması, öğrencilerin kendilerini ifade etmelerini sağlama, öğrencilerle beraber kurallar belirleme, psiko-sosyal ve eğitsel destek sağlama, okul kurallarını uygulama, okulda konferanslar düzenleme, okul dışından destek sağlama, velilerle iş birliği içinde olma, öğrencilerle iletişim kurma, sosyal etkinlikler düzenleme, okulda panolar oluşturma, öğrencileri bilgilendirme ve emniyet güçleri ile tedbirler alma şeklinde etkinlikler yapılabilir. Okullarda zorbalık davranışını önlemek için toplumda iletişim kanallar ile topluma farkındalık eğitimi verilmelidir.

Sonuç olarak, bu sistematik derlemede incelenen çalışmalar zorbalık davranıșını önlemek için literatüre katkı sağlamaktadır. Okul sağlığı hemşirelerine ve diğer araştırmacılara rehberlikte etmektedir. Okul temelli zorbalık davranışını önleme programlarının etkisini değerlendirmek için modellere dayalı çalışmalara, dezavantajlı gruplara yönelik, ebeveyn ve okul görevlilerinin dahil edildiği ve uzun vadede yapılan kanıta dayalı çalışmalara ihtiyaç bulunmaktadır.

Derlenen çalışmada, dezavantajlı gruplar hakkında yapılan araştırmaların sayısının az olması dikkat çekmektedir. Derlenen çalışmaların aranan veri tabanlarında, dezavantajlı gruplar hakkında makaleler bulunmakta fakat bunlara tam metin olarak ulaşılamamıştır. Bu durum derlenen çalışmaya sınırlama getirmektedir.

\section{KAYNAKÇA}

Akcan, A., ve Ergun, A. (2019). The effect of an aggressive behavior prevention program on kindergarten students. Public Health Nursing, 36(3), 330-340. https://doi.org/10.1111/phn.12575

Akyüz, A., ve Koç, Z. (2020). Empati yönelimli siber zorbalık psiko-eğitim programının lise 9. ve 10. sınıf öğrencilerinin siber zorbalık ve empati düzeylerine etkisi. Gazi Üniversitesi Gazi Ĕ̆itim Fakültesi Dergisi, 40 (1), 75-111. https://doi.org/10.17152/gefad.695923

Albayrak, S., Yıldız, A., ve Erol, S. (2016). Assessing the effect of school bullying prevention programs on reducing bullying. Children And Youth Services Review, 63, 19. https://doi.org/10.1016/j.childyouth.2016.02.005

Allen, J.P., Hafen, C.A., Gregory, A.C., Mikami., A.Y., ve Pianta, R. (2015). Enhancing secondary school instruction and student achievement: Replication and extension of the my teaching partner-secondary intervention. Journal of Research on Educational Effectiveness, 8(4),475-489. https://doi.org/10.1080/19345747.2015.1017680

Anticich, S. A. J., Barrett, P. M., Silverman, W., Lacherez, P., ve Gillies, R. (2013). The prevention of childhood anxiety and promotion of resilience among preschool-aged children: A universal school based trial. Advances in School Mental Health Promotion, 6(2), 93-121. https://doi.org/10.1080/1754730X.2013.784616 
Arslan, N., ve Akın, A. (2016). Çözüm Odaklı Kısa Süreli Grupla Psikolojik Danışmanın Lise Öğrencilerinin Akran Zorbalığına Etkisi. Sakarya University Journal of Education, 6(1), 72 84. http://dx.doi.org/10.19126/suje.62580

Avşar, F., ve Ayaz Alkaya, S. (2017). The effectiveness of assertiveness training for school-aged children on bullying and assertiveness level. Journal of Pediatric Nursing, 36, 186190. https://doi.org/10.1016/j.pedn.2017.06.020

Avşar, F., ve Ayaz Alkaya, S. 2018). Akran zorbalığının önlenmesinde okul sağlığı hemşiresinin rolü. Journal of Hacettepe University Faculty of Nursing, 5(1), 78-84. https://doi.org/10.31125/hunhemsire.431134

Banks, R. (1997). Bullying in school. ERİC Diges. https://www.ericdigests.org/19974/bullying.htm.

Barkoukis, V., Lazuras, L., Ourda, D., ve Tsorbatzoudis, H. (2016). Tackling psychosocial risk factors for adolescent cyberbullying: Evidence from a school-based intervention. Aggressive Behavior, 42(2), 114-22 . https://doi.org/10.1002/ab.21625

Barzilay, S., Brunstein Klomek, A., Apter, A., Carli, V., Wasserman, C., Hadlaczky, G., Hoven, C.W., Sarchiapone, M., Balazs, J., Kereszteny, A., Brunner, R., Kaess, M., Bobes, J., Saiz, P., Cosman, D., Haring, C., Banzer, R., Corcoran, P., Kahn, J.P., Postuvan, V., Podlogar, T., Sisask, M., Varnik, A., ve Wasserman, D. (2017). Bullying victimization and suicide Ideation and behavior among adolescents in europe: a 10-country study. Journal of Adolescent Health, 61(2), 179-186. http://dx.doi.org/10.1016/j.jadohealth.2017.02.002

Biswas, T., Scott, J.G., Munir, K., Thomas, H.J., Huda, M.M., Hasan, M.M., David de Vries, T., Baxter, J., ve Mamun, A.A. (2020). Global variation in the prevalence of bullying victimisation amongst adolescents: role of peer and parental supports. EClinicalMedicine, 20, Article 100276. https://doi.org/10.1016/j.eclinm.2020.100276

Bonell, C., Allen, E., Warren, E., McGowan, J., Bevilacqua, L., Jamal, F., Legood, R., Wiggins, M., Opondo, C., Mathiot, A., Sturgess, J., Fletcher, A., Sadique, Z., Elbourne, D., Christie, D., Bond, L., Scott, S., ve Viner, R.M. (2018). Effects of the learning together intervention on bullying and aggression in english secondary schools (INCLUSIVE): a cluster randomised controlled trial. Lancet, 392(10163), 2452-2464. https://doi.org/10.1016/S01406736(18)31782-3

Bonell, C., Mathiot, A., Allen, E., Bevilacqua, L., Christie, D., Elbourne, D., Fletcher, A., Grieve, R., Legood, R., Scott, S., Warren, E., Wiggins, M., ve Viner, R.M. (2017). Initiating change locally in bullying and aggression through the school environment (INCLUSIVE) trial: update to cluster randomised controlled trial protocol. Trials, 18(1), 238. https://doi.org/10.1186/s13063-017-1984-6

Bowes, L., Aryani, F., Ohan, F., Haryanti, R. H., Winarna, S., Arsianto, Y., Budiyawati, H., Widowati, E., Saraswati, R., Kristianto, Y., Suryani, Y. E., Ulum, D. F., ve Minnick, E. (2019). The development and pilot testing of an adolescent bullying intervention in Indonesia the ROOTS Indonesia program. Global health action,12(1), Article 1656905. https://doi.org/10.1080/16549716.2019.1656905

Centers For Disease Control And Prevention. (2014). Bullyıng survellance among youths: uniform definitions for public health and recommended data elements. National Center for Injury Prevention and Control Https://www.cdc.gov/Violenceprevention/Youthviolence/Bullyingresearch/Fastfact.Ht $\mathrm{ml}$

Centers For Disease Control And Prevention. (2020, 21 October). Preventing bullying. https://www.cdc.gov/violenceprevention/youthviolence/bullyingresearch/fastfact.html 
Christian Elledge, L., Williford, A., Boulton, A.J., Depaolis, K.J., Little, T.D., ve Salmivalli, C. (2013). Individual and contextual predictors of cyberbullying: the influence of children's provictim attitudes and teachers' ability to intervene. Journal of Youth and Adolescence, 42(5), 698-710. https://doi.org/10.1007/s10964-013-9920-x

Cipra, A., ve Hall, L. (2019). COREMatters: a bullying intervention pilot study. Research in Middle Level Education, 42(6), 1-14. https://doi.org/10.1080/19404476.2019.1599244

Clarkson, S., Axford, N., Berry, V., Edwards, R.T., Bjornstad, G., Wrigley, Z., Charles, J., Hoare, Z., Ukoumunne, O.C., Matthews, J., ve Hutchings, J. (2016). Effectiveness and micro-costing of the KiVa school-based bullying prevention programme in Wales: study protocol for a pragmatic definitive parallel group cluster randomised controlled trial. BMC Public Health, 1(16), 104. https://doi.org/10.1186/s12889-016-2746-1

Clarkson, S., Charles, J.M., Saville, C.W.N., Bjornstad, G.J., ve Hutchings, J. (2019). Introducing KiVa school-based antibullying programme to the UK: A preliminary examination of effectiveness and programme cost. School Psychology International, 40(4), 347-365. https://doi.org/10.1177/0143034319841099

Costantino, C., Casuccio, A., Marotta, C., Bono, S. E., Ventura, G., Mazzucco, W., Vitale, F., ve Restivo, V. (2019). Effects of an intervention to prevent the bullying in first-grade secondary schools of palermo, Italy: The BIAS Study. Italian Journal of Pediatrics, 45(1). https://doi.org/10.1186/s13052-019-0649-3

Cross, D., Shaw, T., Hadwen, K., Cardoso, P., Slee, P., Roberts, C., Thomas, L., ve Barnes, A. (2016). Longitudinal impact of the cyber friendly schools program on adolescents' cyberbullying behavior. Aggressive Behavior, 42(2), 166-180. https://doi.org/10.1002/ab.21609

Dağhan, Ş. (2017). "Halk Sağlığı Hemşireliği Felsefesiyle Hemşire Olmak" Anlamı Nedir?. Dokuz Eylül Üniversitesi Hemşirelik Fakültesi Elektronik Dergisi, 10(2), 107-112. https://dergipark.org.tr/tr/pub/deuhfed/issue/46791/586752

Day, J.K., Fish, J.N., Grossman, A.H., ve Russell, S.T. (2020). Gay-Straight alliances, Inclusive policy, and school climate: LGBTQ youths' experiences of social support and bullying. Journal of Research on Adolescence, 30(52), 418-430. https://doi.org/10.1111/jora.12487

Diamond, A., Lee, C., Senften, P., Lam, A., ve Abbott, D. (2019). Randomized control trial of Tools of the Mind: Marked benefits to kindergarten children and their teachers. PLOS ONE, 14(9), 1-27. https://doi.org/10.1371/journal.pone.0222447

Doane, N.A., Kelley, L.M., ve Pearson, R.M. (2016). Reducing cyberbullying: a theory of reasoned action-based video prevention program for college students. Aggressive Behavior, 42(2), 136-146. https://doi.org/10.1002/ab.21610

Doğan, A., Keser, E., Şen, Z., Yanagida, T., Gradinger, P., ve Strohmeier, D. (2017). Evidence based bullying prevention in Turkey: implementation of the ViSC social competence program. International Journal of Developmental Science, 11(3-4), 93108. https://doi.org/10.3233/DEV-170223

Doumas, D.M., Midgett, A., ve Watts, A.D. (2019). A pilot evaluation of the social validity of a bullying bystander program adapted for high school students. Psychology in the Schools, 56(7), 1101-1116. https://doi.org/10.1002/pits.22249

Espelage, D.L., Low, S., Polanin, J.R., ve Brown, E.C. (2013). The impact of a middle school program to reduce aggression, victimization, and sexual violence. Journal of Adolescent Health, 53(2), 180-6. https://doi.org/10.1016/j.jadohealth.2013.02.021

Evgin, D., ve Bayat, M. (2020). The Effect of Behavioral System Model Based Nursing Intervention on Adolescent Bullying. Florence Nightingale journal of nursing (Online), 28(1), 71-82. https://doi.org/10.5152/FNJN.2020.18061 
Farmer, V.L., Williams, S.M., Mann, J.I., Schofield, G., McPhee, J.C., ve Taylor, R.W. (2017). Change of school playground environment on bullying: a randomized controlled trial. Pediatrics, 139(5), Article e20163072. https://doi.org/10.1542/peds.2016-3072

Farrell, A.D., Sullivan, T.N., Sutherland, K.S., Corona, R., ve Masho, S. (2018). Evaluation of the Olweus bully prevention program in an urban school system in the USA. Prevention Science, 19(6), 833-847. https://doi.org/10.1007/s11121-018-0923-4

Federici, R.A. Flato, M. Bru, L.E. Midthassel, U.V. Helleve, A., ve Ronsen, E. (2019). Can school nurses improve the school environment in Norwegian primary schools? A protocol for a randomized controlled trial. International Journal of Educational Research, 96, 63-80. https://doi.org/10.1016/j.ijer.2019.05.008

Fischer, S.M., ve Bilz, L. (2019). Teachers' self-efficacy in bullying interventions and their probability of intervention. Psychology in the Schools, 56(5) 1086-1097. https://doi.org/10.1002/pits.22229

Fisher, K., Cassidy, B., Ren, D., ve Mitchell, A.M. (2018). Implementation of a school-based bullying program. Journal of Community Health Nursing, 35(2), 41-48. https://doi.org/10.1080/07370016.2018.1446631

Gaete, J., Valenzuela, D., Rojas-Barahona, C., Valenzuela, E., Araya, R., ve Salmivalli., C. (2017). The KiVa antibullying program in primary schools in Chile, with and without the digital game component: study protocol for a randomized controlled trial. Trials, 18(1), 75. https://doi.org/10.1186/s13063-017-1810-1

Gouveia, P., Leal, I., ve Cardoso, J. (2019). Preventing and reducing school violence: development of a Student and Family office a pilot study. Educational Psychology in Practice, 35,(1) 6781. https://doi.org/10.1080/02667363.2018.1532875

Gradinger, P., Yanagida, T., Strohmeier, D., ve Spiel, C. (2016). Effectiveness and sustainability of the ViSC social competence program to prevent cyberbullying and cyber-victimization: class and individual level moderators. Aggressive Behavior, 42(2), 181-93. https://doi.org/10.1002/ab.21631

Grassetti, S. N., Hubbard, J. A., Smith, M. A., Bookhout, M. K., Swift, L. E., ve Gawrysiak, M.J. (2018). Caregivers' advice and children's bystander behaviors during bullying incidents. Journal of Clinical Child and Adolescent Psychology, 47(Suppl 1), S329S340. https://doi.org/10.1080/15374416.2017.1295381

Gregory, A., Hafen, C.A., Ruzek, E. Mikami, A.Y. Allen, C.P., ve Pianta, R.C. (2016). Closing the racial discipline gap in classrooms by changing teacher practice. School Psychology Review, 45(2), 171-191. https://doi.org/10.17105/SPR45-2.171-191

Healy, K,L., ve Sanders, M.R. (2017). Antecedents of treatment resistant depression in children victimized by peers. Child Psychiatry \& Human Development, 48(1), 107-119. https://doi.org/10.1007/s10578-016-0658-z

Hoover, D.W., ve Kaufman, J. (2018). Adverse childhood experiences in children with autism spectrum disorder. Current Opinion in Psychiatry, 31(2), 128-132. https://doi.org/10.1097/YCO.0000000000000390

Hormazábal-Aguayo, I., Fernández-Vergara, O., González-Calderón, N., Vicencio-Rojas, F., RussellGuzmán, J., Chacana-Cañas, C., Del Pozo-Cruz, B., ve García-Hermoso, A. (2019). Can a before-school physical activity program decrease bullying victimization in disadvantaged children? The active-start study. International Journal of Clinical and Health Psychology, 19(3), 237-242. https://doi.org/10.1016/j.ijchp.2019.05.001

Huitsing, G., Lodder, G. M. A., Oldenburg, B., Schacter, H. L., Salmivalli, C., Juvonen, J., ve Veenstra, R. (2019). The healthy context paradox: victims' adjustment during an anti-bullying 
intervention. Journal of Child and Family Studies, 28(9), 24992509. https://doi.org/10.1007/s10826-018-1194-1

Hutson, E., Kelly, S., ve Militello, L.K. (2018). Systematic review of cyberbullying interventions for youth and parents with implications for evidence-based practice. Worldviews on Evidence-Based Nursing, 15(1),72-79. https://doi.org/10.1111/wvn.12257

Karaçam, Z. (2013). Sistematik derleme metodolojisi: Sistematik derleme hazırlamak için bir rehber. Dokuz Eylül Üniversitesi Hemşirelik Yüksekokulu Elektronik Dergisi, 6(1), 26- 33. https://dergipark.org.tr/tr/pub/deuhfed/issue/46815/587078

Karataş, H. (2011). İlköğretim okullarında zorbalığa yönelik geliștirilen programın etkisinin incelenmesi [Yayınlanmamış Doktora Tezi]. Dokuz Eylül Üniversitesi.

Karataş, H., ve Öztürk, C. (2020). Examining the effect of a program developed to address bullying in primary schools. The Journal of Pediatric Research, 7(3), 243-9. https://doi.org/10.4274/jpr.galenos.2019.37929

Klippel, A., Reininghaus, U., Viechtbauer, W., Decoster, J., Delespaul, P., Derom, C., de Hert, M., Jacobs, N., Menne-Lothmann, C., Rutten, B., Thiery, E., van Os, J., van Winkel, R., MyinGermeys, I., ve Wichers, M. (2018). Sensitivity to peer evaluation and its genetic and environmental determinants: findings from a population-based twin study. Child Psychiatry \& Human Development, 49(5), 766-778. https://doi.org/10.1007/s10578018-0792-x

Kosciw, J. G., Greytak, E. A., Zongrone, A. D., Clark, C. M., ve Truong, N. L. (2018). The 2017 national school climate survey: The experiences of lesbian, gay, bisexual, transgender, and queer youth in our nation's schools. New York, NY: GLSEN. https://eric.ed.gov/?id=ED590243

Mann, M.J., Kristjansson, A.L., Sigfusdottir, I.D., ve Smith, M.L. (2015). The role of community, family, peer, and school factors in group bullying: implications for school-based intervention. Journal of School Health, 85(7), 477-86. https://doi.org/10.1111/josh.12270

McFarlane, J., Karmaliani, R., Maqbool Ahmed Khuwaja, H., Gulzar, S., Somani, R., Saeed Ali, T., Somani, Y.H., Shehzad Bhamani, S., Krone, R.D., Paulson, R.M., Muhammad, A., ve Jewkes, R. (2017). Preventing peer violence against children: methods and baseline data of a cluster randomized controlled trial in Pakistan. Global Health: Science and Practice, 5(1), 115-137. https://doi.org/10.9745/GHSP-D-16-00215

Midgett, A., Doumas, D. M., ve Johnston, A. D. (2018). Establishing school counselors as leaders in bullying curriculum delivery. Professional School Counseling, 21(1), 19. https://doi.org/10.1177/2156759X18778781

Midgett, A., Doumas, D.M., Myers, V.H., Moody, S., ve Doud, A. (2021). Technology-based bullying intervention for rural schools: perspectives on needs, challenges, and design. Journal of Rural Mental Health, 45(1), 14-30. https://doi.org/10.1037/rmh0000151

Midgett, A., ve Doumas, D.M. (2016). Training elementary school students to intervene as peeradvocates to stop bullying at school: a pilot study. Journal of Creativity in Mental Health, 11(3), 353-365. https://doi.org/10.1080/15401383.2016.1164645

Miyazaki, S., Abe, T., Iimura, K., Waki, H., Okuma, K., ve Mukainov, Y. (2016). Graded meridian test program to prevent bullying: preliminary study. Traditional \& Kampo Medicine, 3(1), 50-58. https://doi.org/10.1002/tkm2.1038

Muratori, P., Giuli, C., Bertacchi, I., Orsolini, L., Ruglioni, L., ve Lochman, J.E. (2017). Coping power for preschool-aged children: a pilot randomized control trial study. Early Intervention in Psychiatry, 11(6), 532-538. https://doi.org/10.1111/eip.12346 
Naidoo, S. Satorius, B.K., De Vreis, H., ve Taylor, M. (2016). Verbal bullying changes among students following an educational intervention using the integrated model for behavior change. Journal Of School Health, 86(11), 813-22. https://doi.org/10.1111/josh.12439

Nedim Bal, P., ve Kahraman, S. (2015). The effect of cyber bullying sensibility improvement group training program on gifted students. Journal of Gifted Education Research, 3(2), 485. https://www.researchgate.net/publication/331319083_The_Effect_of_Cyber_Bullyin Sensibility_Improvement_Group_Training_Program_on_Gifted_Students

Newgent, R. A., Beck, M. J., Kress, V. E., ve Watkins, M. C. (2016). Social and relational aspects of bullying and victimization in elementary school: strength-based strategies for prevention. Journal of Creativity in Mental Health, 11(3-4), 285-297. https://doi.org/10.1080/15401383.2016.1222921

Olatunbosun, I. (2016). Efficacy of cognitive behaviour therapy on reducing bullying behaviour among secondary school students in ikwerre local government area. Academia Journal of Educational Research, 4(1), 001-007. https://doi.org/10.15413/ajer.2015.0125

Olweus, D. (1994). Bullying at school: basic facts and effects of a school based intervention program. Journal of Child Psychology and Psychiatry, 35(7), 117190. https://doi.org/10.1111/j.1469-7610.1994.tb01229.x.

Olweus, D. (2003). A profile of bullying at school. Educational Leaderships, 60(6), 12-17. http://www.ascd.org/publications/educational-leadership/mar03/vol60/num06/AProfile-of-Bullying-at-School.aspx

Olweus, D., Solberg, M.E., ve Breivik, K. (2020). Long-term school-level effects of the Olweus Bullying Prevention Program (OBPP). Scandinavian Journal of Psychology, 1(1), 108-116. https://doi.org/10.1111/sjop.12486

Organisation for Economic Co-operation and Development. (2017). PISA 2015 results (volume 111): students'well-being. PISA, OECD Paris. https://doi.org/10.1787/9789264273856-en

Ortiz-Bush, Y., ve Schultz, R. (2016). A collaborative bullying prevention project. Journal of Creativity in Mental Health, 11(3-4), 343-352. https://doi.org/10.1080/15401383.2016.1244500

Özbay, A. (2017). Sanal Zorbalı̆̆a Maruz Kalan Ergenlerin Çözüm Odaklı Kısa Süreli Terapi Yönelimli Psikoeğitim Programının Psikolojik Belirtiler ve Sanal Mağduriyete Etkisi [Yayınlanmamış Doktora Tezi]. Sakarya Üniversitesi.

Özbey, H., ve Başdaş, Ö. (2020). Ergenlerde zorbalık ve hemşirelik yaklaşımı. ERÜ Sağlık Bilimleri Fakültesi Dergisi, $7(1), \quad 46-50$. https://dergipark.org.tr/tr/pub/erusaglik/issue/55114/706420

Palladino, B.E., Nocentini, A., ve Menesini, E. (2016). Evidence-based intervention against bullying and cyberbullying: Evaluation of the NoTrap! program in two independent trials. Aggressive Behavior, 42(2), 194-206. https://doi.org/10.1002/ab.21636

Pişkin, M. (2002). Okul zorbalığı: tanımı, türleri, ilişkili olduğu faktörler ve alınabilecek önlemler. Kuram ve Uygulamada Eğitim Bilimleri, 2(2), 531-562. https://app.trdizin.gov.tr/makale/TWpFME1qST0/okul-zorbaligi-tanimi-turleri-iliskilioldugu-faktorler-ve-alinabilecek-onlemler

Rana, M., Gupta, M., Malhi, P., Grover, S., ve Kaur, M. (2018). Effectiveness of a multicomponent school based intervention to reduce bullying among adolescents in chandigarh, North India: a quasi-experimental study protocol. Journal of public health research, 7(1), 1304. https://doi.org/10.4081/jphr.2018.1304 
Rex, C., Charlop, M.H., ve Spector, V. (2018). Using video modeling as an anti-bullying intervention for children with autism spectrum disorder. Journal of Autism and Developmental Disorders, 48(8), 2701-2713. https://doi.org/10.1007/s10803-018-35278

Saarento, S., Boulton, A.J., ve Salmivalli, C. (2015). Reducing bullying and victimization: student and classroom- level mechanisms of change. Journal of Abnormal Child Psychology, 43(1), 61-76. https://doi.org/10.1007/s10802-013-9841-x

Saını, M., Herkama, S., Turunen, T., Rönkkö, M., Kontio, M., Poskiparta, E., ve Salmivalli, C. (2020). Sustainable antibullying program implementation: school profiles and predictors. Scandinavian Journal of Psychology, 61(1), 32-142. https://doi.org/10.1111/sjop.12487

Salmeron, P.A., ve Christian, J.C. (2016). Evaluation of an educational program to improve school nursing staff perceptions of bullying in pinellas county, Florida. Pediatric Nursing, 42(6), 283-93. http://web.b.ebscohost.com/ehost/results?vid=2\&sid=a2d0bf2f-422c-497b81fc-b66aac245143\%40pdc-v-

sessmgr02\&bquery=Evaluation+of + an + Educational+Program+To+Improve+School+Nur sing + Staff + Perceptions + of + Bullying $+I n+$ Pinellas + County $\% 2 c+$ Florida\&bdata $=J m R i P W F z$ biZ0eXBIPTAmc2VhcmNoTW9kZT1TdGFuZGFyZCZzaXRIPWVob3N0LWxpdmU\%3d

Santos, R.G., Chartier, M.J., ve Whalen, J.C. (2011). Chateau D, Boyd L. Effectiveness of schoolbased violence prevention for children and youth: a research report. Healthcare Quarterly, 14(2), 80-91. https://doi.org/10.12927/hcq.2011.22367

Shinde S., Weiss, H.A., Khandeparkar, P., Pereira, B., Sharma, A., Gupta, R., Ross, D.A., Patton, G., ve Patel, V.A. (2020). Multicomponent secondary school health promotion intervention and adolescent health: an extension of the SEHER cluster randomised controlled trial in Bihar, India. PLOS Medicine, 17(2), Article e1003021. https://doi.org/10.1371/journal.pmed.1003021

Shinde, S., Weiss H.A., Varghese, B., Khandeparkar, P., Pereira, B., Sharma, A., Gupta, R., Ross, D.A., Patton, G., ve Patel, V. (2018). Promoting school climate and health outcomes with the SEHER multi-component secondary school intervention in Bihar, India: a clusterrandomised controlled trial. Lancet, 392(10163), 2465-2477. https://doi.org/10.1016/S0140-6736(18)31615-5

Smith, A.U., ve Norris, A.E. (2018). Parent communication and bullying among hispanic adolescent girls. The Journal of School Nursing, 36(3), 222-232. https://doi.org/10.1177/1059840518808013

Song, K., Lee, S., ve Park, S. (2018). How individual and environmental factors influence teachers' bullying intervention. Psychology in the Schools, 55(9) 1086-1097. https://doi.org/10.1002/pits.22151

Srabstein, J.C., ve Leventha, B.L. (2010). Prevention of bullying-related morbidity and mortality: a call for public health policies. Bull World Health Organ, 88, 403-404. https://doi.org/10.2471/BLT.10.077123

The PRISMA Statement. (2021, February 4). PRISMA Statement. http://www.prismastatement.org/PRISMAStatement/

Timmons-Mitchell, J. Levesque, D.A. Harris III, L.A. Flannery, D.J., ve Falcone, T. (2016). Pilot test of StandUp, an online school-based bullying prevention program. Children \& Schools, 38(2), 71-80. https://doi.org/10.1093/cs/cdw010 
United Nations Children's Fund. (2018, 6 September). An everyday lesson \#endviolence in schools. United Nations Children's Fund (UNICEF). https://www.unicef.org/turkey/raporlar/everyday-lesson-endviolence-schools-2018

Van Niejenhuis, C., Huitsing, G., ve Veenstra, R. (2020). Working with parents to counteract bullying: A randomized controlled trial of an intervention to improve parent-school cooperation. Scandinavian Journal of Psychology, 61(1), 117-131. https://doi.org/10.1111/sjop.12522

Van Ryzin, M.J., ve Roseth, C.J. (2019). Effects of cooperative learning on peer relations, empathy, and bullying in middle school. Aggressive behavior, 45(6), 643-651. https://doi.org/10.1002/ab.21858

Vives-Cases, C., Davo-Blanes, M.C., Ferrer-Cascales, R., Sanz-Barbero, B., Albaladejo-Blázquez, N., Sánchez-San Segundo, M., Lillo-Crespo, M., Bowes, N., Neves, S., Mocanu, V., Carausu, E.M., Pyżalski, J., Forjaz, M.J., Chmura-Rutkowska, I., Vieira, C.P., ve Corradi, C. (2019) Lights4Violence: A Quasi-Experimental Educational İntervention İn Six European Countries To Promote Positive Relationships Among Adolescents. BMC Public Health, 19(1), 389. https://doi.org/10.1186/s12889-019-6726-0

Wang, C., ve Goldberg, T. S. (2017). Using children's literature to decrease moral disengagement and victimization among elementary school students. Psychology in the Schools, 54(9), 918-931. https://doi.org/10.1002/pits.22042

Willging, C.E., Green, A.E., ve Ramos, M.M. (2016). Implementing school nursing strategies to reduce LGBTQ adolescent suicide: a randomized cluster trial study protocol. Implementation Science, 11(1), 145. https://doi.org/10.1186/s13012-016-0507-2

Wójcik, M., ve Hełka, A.M. (2019). Meeting the Needs of Young Adolescents: ABBL Anti-Bullying Program During Middle School Transition. Psychological Reports, 122(3), 1043-1067. https://doi.org/10.1177/0033294118768671

World Health Organization. (2019). School-based violence prevention: a practical handbook. World Health Organization. https://apps.who.int/iris/handle/10665/324930

Ye, L., Wang, L., Ferdinando, H., Seppänen, T., ve Alasaarela, E. (2020). A Video-Based DT-SVM School Violence Detecting Algorithm, Sensors (Basel), 20(7), 1-18. https://doi.org/10.3390/s20072018

Yelboğa, N., ve Koçak, O.(2019). Ergenlerde Akran Zorbalığını Yordayan Bazı Faktörlerin Zorba ve Mağdur Bireyler Açısından Değerlendirilmesi. OPUS Uluslararası Toplum Araştırmaları Dergisi, 13(19), 2286-2320. https://doi.org/10.26466/opus.543567

Yıldırım, J., Ardahan, M., ve Kurt, A. (2021). Ebeveynlerin Okul Sağlığı Hemşiresinin Rollerini Algllamaları. İzmir Katip Çelebi Üniversitesi Sağlık Bilimleri Fakültesi Dergisi, 6(2), 85-91. https://dergipark.org.tr/en/pub/ikcusbfd/issue/62599/892916

Yokoo, M., Wakuta, M., ve Shimizu, E. (2018). Educational Effectiveness of a Video Lesson for Bullying Prevention. Children \& Schools, 40(2), 71-80. https://doi.org/10.1093/cs/cdy001

Yurdakul, Y. (2020). Siber zorbalık farkındalık programının ergenlerin siber zorbalığa ilişkin farkındalıklarına ve siber zorbalıkla baş etme becerilerine etkisinin incelenmesi [Yayınlanmamış Doktora Tezi]. Ankara Üniversitesi.

Zambuto, V., Palladino, B.E., Nocentini., A., ve Menesini, E. (2019). Why do some students want to be actively involved as peer educators, while others do not? Findings from NoTrap! anti-bullying and anti-cyberbullying program. European Journal of Developmental psychology, 16(4), 3734-386. https://doi.org/10.1080/17405629.2017.1419954 


\section{EKLER}

\section{Araştırmaların Sonuçları}

Derleme kapsamına alınan randomize kontrollü çalışmalarda Clarkson ve arkadaşları (2016). yaptığı çalışmada tam model, geçersiz modele göre $(X 21=6.4443, P=0.011)$; mağdur sayılarında istatistiksel olarak bir düşme $(\mathrm{t}=2.68, \mathrm{~d}=-0.99)$; tam model, geçersiz modele göre mağdurların zorbalık davranışını önlemede (AIC: 6575.652 vs 6579.950; X21=6.298, P=0.012), KIVA eğitim modelinin okullarda etkinliğini göstermek için tam model ile model olmadan rastgele zaman eğilimleri arasında olasılık testi $(X 21=6.4826, \mathrm{P}=0.03911)$ anlamlı olarak tespit etmiştir. Gregory ve arkadaşları (2016). yaptığı çalışmada öğretmenlerin yaşam koçluğu modelinin zorbalık davranışı üzerinde etkisi incelenmiştir. Çalışmada öğretmenlerin siyah öğrencilere disiplin uygulaması diğer öğrencilere kıyasla az uyguladığı $(\mathrm{d}=0.24)$ tespit edilmiştir. Disiplin uygulamalarının siyah olmayan öğrencilerde yeterli oranda anlamlı $(d=0.11)$. olmadığı tespit edilmiştir. Kızlar, erkeklere kıyasla Bb $\left(.03^{*} ;{ }^{*} \mathrm{P}<.05\right)$; SE, $(.01)$; 95 \% CI $(.003, .062)$; Müdahale gurubu, kontrol grubuna göre $\mathrm{Bb}\left(.07^{* *} ;{ }^{* *} \mathrm{P}<.01\right)$; $\mathrm{SE},(.02)$; 95 \% CI (.079, -.013) anlamlı bulunmuştur. Ayrıca programın etkinliği uzun süreli devam ettiği $\mathrm{Bb}\left(.05^{* *} ;{ }^{* *} \mathrm{P}<.01\right)$; SE, (.02); 95 \% CI $(-.074,-.011)$ tespit edilmiştir.

Cross ve arkadaşları (2016). yaptığı çalışmada 3 yıl izlenen öğrenciler, yapılan çalışmanın tablo 2'de ikili bölümünde belirtildiği gibi 1. yıldan 2. yıla geçişte siber zorbalığa maruz kaldığı $(\mathrm{P}=.034 ; \mathrm{P}<.05 ; \mathrm{d} 2=.07)$, fakat tek bölümünde 1.yıldan 2. yıla $(\mathrm{P}=.006 ; \mathrm{P}<.01$; $\mathrm{d}=.09)$ ve 2.yıldan 3. yıla $(\mathrm{P}=.012 ; \mathrm{P}<.05 ; \mathrm{d}=.09)$ geçişte siber zorbalığa maruz kaldığı; aynı tabloda öğrencilerin siber suç işleme meyilleri 1.ylldan 2. ylla $(\mathrm{P}=.049 ; \mathrm{P}<.05 ; \mathrm{d}=06)$ ve 2.yldan 3. yıla $(\mathrm{P}=.006 ; \mathrm{P}<.01 \mathrm{~d}=.0007)$ olduğu tespit edilmiştir. Yapılan çalışmanın Tablo 3'te öğrencilerin siber suç işleme $(\mathrm{P}=.028 ; \mathrm{P}<.05 ; \mathrm{d}=.07)$ ve siber zorbalığa maruz kalma davranışını $(\mathrm{P}=.012 ; \mathrm{P}<.05 ; \mathrm{d}=0.86)$ azalttığı tespit edilmiştir. Naidoo ve arkadaşları (2016). yaptığ çalışmada Müdahale grubunda, sözlü zorbalık bilgi düzeyinde artış $(\mathrm{p}<.001)$, sözlü zorbalığı engelleyen tutumlar $(\mathrm{p}=.001)$, sözlü zorbalık yapmama niyetleri $(\mathrm{p}=.010)$, gelecekte sözlü zorbalığa karşı bir eylem planına sahip olma durumu ( $\mathrm{p}=.004)$, çevresinde sözlü insanlarla ilişki kurma ( $\mathrm{p}=.030)$, sözlü zorbalık yaşama ( $\mathrm{p}=.043)$ faktörlerinde azalış tespit edilmiştir. Kontrol grubu öğrencileri arasında sözel zorbalık bilgi düzeyinde önemli değişimler olmuştur ( $p=.022)$, karşı tutumlar ( $p=.016)$ ve önleme ( $p=.002)$ sözel zorbalığı önleyen düzenli öz yeterlik ( $p=.013)$, sözlü zorbalığı önleyen durumsal öz yeterlik ( $\mathrm{p}=.043$ ), sözlü zorbalığa karşı bir eylem becerisine sahip olmak ( $\mathrm{p}=.015)$ anlamlı farklılar olmuştur.

Muratori ve arkadaşları (2017). yaptığı çalışmada genel stres faktörü $(d=0.18$; Ftime:8.66*; ${ }^{* * P}<0.01$ ). Davranışsal zorluk faktörü ( $d=0.25$; Ftime: $3.56^{*}$; $\left.{ }^{*} \mathrm{P}<0.05\right)$. Sosyal yanlısı davranış faktöründe ( $\mathrm{d}=0.23$; Ftime: $9.56^{* *}$; ${ }^{* *} \mathrm{P}<0.01$ ) ve Hiperaktif akran Problemleri 
(0.08) ve Pro-sosyal davranışta (0.30); duygusal problemler (0.09); Davranışsal zorluklar için (0.06); hiperaktif (0.07); akran problemleri (0.17) ve Pro-sosyal davranış (0.17) anlamlı olarak tespit edilmiştir. Bonell ve arkadaşları (2017). yaptığı çalışmada her 20 okul'a \%5 anlamlılık seviyesi ile etki boyutu 0.25 olan çalışma $90 \%$ güç sağlayacağ tespit edilmiştir. Gaete ve arkadaşları (2017). yaptığı çalışmada ( $\mathrm{d}=0.63)$ tespit edilirken öğrencilerde akademik performansta iyileşme, güçlü okul bağları, okulda kötü davranış olasılığının azalması, madde kullanımında azalma, öz-yeterlilikte artma gibi olumlu gelişmeler tespit edilmiştir. Farmer ve arkadaşları (2017). yaptığı çalışmada müdahale grubunda öğrencilerin daha mutlu olduğu (odds ratio [OR]: 1.64; 95\% güven aralığı [CI]: 1.20-2.25), daha fazla çocuk ile oynamak (1 yllda, OR: 1.66; 95\% CI: 1.29-2.15), Müdahale grubundakiler daha fazla itilmişlik yaşarken (OR: 1.33; 95\% CI: 1.03-1.71) 2 yılda öğretmenlere söyleme oranı düşmüştür (OR: 0.69; 95\% CI: 0.52-0.92). Çocuklarının 1 yılda okulda zorbalık bildirme/bildirmeme durumlarında (1 yıl: $\mathrm{P}=.23$; 2 yıl: $\mathrm{P}=$ .07). önemli bir bulgu elde edilmemiştir. 1 yll içinde müdahale grubu öğretmenleri, kontrol grubuna göre daha fazla zorbalık davranışı fark etmiştir (puanlardaki fark: 0.20; 95\% CI: 0.060.34; $\mathrm{P}=$.009), öğretmenlere bildirilen zorbalık davranışında artış olmamıştır ( $\mathrm{P} \geq .26)$. Doumas ve arkadaşları (2019). yaptığı çalışmada müdahale grubunun kontrol grubuna göre bilgi düzeyinde ( $\eta 2 p=0.27, p<0.001)$; müdahale güveninde ( $\eta 2 p=0.27, p<0.001)$ olduğu tespit edilmiştir.

Federici ve arkadaşları (2019). yaptığı çalışmada okul hemşiresi olan okullarda, öğrencilerin akademik performansı $(\mathrm{p}<0.05)$, okula uyum hali $(\mathrm{p}<0.05)$, okula aidiyet duygusu $(p<0.05)$, öğrencilerin derse katılımı $(p<0.05)$, benlik kavramı $(p<0.05)$, motivasyon ve okula devamsızlığı azalttığına $(\mathrm{p}<0.05)$, dair önemli sonuçları olduğu tespit edilmiştir. HormazábalAguayo ve arkadaşları (2019). yaptığı çalışma sonucunda fiziksel (OR= 0.18, 95\% CI:0.04-0.82; $\mathrm{P}=.027)$ ve sözel $(\mathrm{OR}=0.13,95 \% \mathrm{CI}: 0.02-0.97 ; \mathrm{P}=.046)$ zorbalıkta azalma tespit edilmiştir. Huitsing ve arkadaşları (2019). yaptığı çalışmada depresif belirtisi ( $M=0.64, S D=0.53)$, Sosyal anksiyete $(M=0.94, S D=0.76)$, öz saygı $(M=3.07, S D=0.83)$ ve okul iyilik hali $(M=2.10, S D=$ 0.57) tespit edilmiştir. Müdahale genel olarak başarılı bulunmuştur fakat kontrol grubundakiler müdahale grubuna göre daha fazla depresif belirti ve düşük benlik saygısı olduğu tespit edilmiştir. Zorbalık davranışında en çok çevrenin etkili olduğu belirtilmiştir. Van Ryzin ve Roseth (2019) yaptığı çalışmada zorbalık ( $\mathrm{r}=-0.06$ için -0.08$)$, Bilişsel ( $\mathrm{r}=0.10$ için 0.11 ), Empati ( $r=0.24$ için 0.29) olarak bulunmuştur. Ayrıca eğitim programının öğrencilerin empati $(\mathrm{p}<.05)$ ve akran ilişkilerine olumlu $(\mathrm{p}<.05)$ etki ettiği tespit edilmiştir. Shinde ve arkadaşları (2020). yaptığı çalışmada okul ortamı $(p<0.001)$, Depresyon $(p<0.001)$, Cinsiyet eșitliğine karşı tutum $(\mathrm{p}<0.001)$, Zorbalık sıklığ $(\mathrm{p}<0.001)$, şiddet mağduriyeti $(\mathrm{p}<0.001)$, Şiddet suçu $(\mathrm{p}<0.001)^{\prime} \mathrm{da}$ anlamlılık tespit edilmiştir. 
Shinde ve arkadaşları (2020). yaptığı çalışmanın sonunda 17 aylık süre ile verilen eğitimlerin, 8 aylık süre ile verilenlere klyasla olumlu sonuçlar tespit edilmiştir. Okul iklimi (etki boyutu [ES; 95\% CI] = 2.23 [1.97-2.50] karşı 1.88 [1.44-2.32], p < 0.001); depresyon (ES [95\% $\mathrm{CI}]=-1.19$ [-1.56 to -0.82$]$ karşı -0.27 [ -0.44 to -0.11$], \mathrm{p}<0.001$ ); Cinsiyet eşitliğine karşı (ES $[95 \% \mathrm{CI}]=0.53[0.27-0.79]$ karşı 0.23 [0.10-0.36], $\mathrm{p}<0.001)$; Zorbalık $(\mathrm{ES}[95 \% \mathrm{CI}]=-2.22$ [ -2.84 to -1.60 ] karşı -0.47 [ -0.61 to -0.33 ], p < 0.001); Şiddet Kurbanı (OR [95\% CI] $=0.08$ [0.04-0.14] karşı 0.62 [0.46-0.84], p < 0.001); Şiddet Suçu (OR [95\% CI] = 0.16 [0.09-0.29] karş1 0.68 [0.48-0.96], p < 0.001) olarak tespit edilmiştir. Van Niejenhuisi ve arkadaşları (2020). yaptığı çalışmada zorbalık davranışını önlemede ebeveyn rolünü etkin bir şekilde ortaya koymuştur. Ebeveyn $(\mathrm{p}<0.10$.) ve okul yöneticilerin $(\mathrm{p}<0.10$.) anlamlı bulunmuştur. Yapılan çalışmada ebeveynin zorbalığı onaylamaması (difference $=0.61$, Cohen's $d=0.47$ ); Zorbalığın önlenmesi ebeveynin sorumluluğunda olması (difference $=0.38$, Cohen's $d=0.39$ ); Ebeveynin öğretmenle işbirliği yapma tutumu zorbalığa karşı mücadele durumu (difference $=0.26$, Cohen's $d=0.47$ ); Öğretmenin, ebeveyni çocukla konuşmaya teşvik etmesi (difference $=0.63$, Cohen's $d=$ $0.63)$ vb. faktörlerde anlamlı sonuçlar bulunmuştur. 


\section{Tablo 1}

Değerlendirmeye alınan çalışmalar

\begin{tabular}{|c|c|c|c|c|c|c|}
\hline & Yazar/yıl & $\begin{array}{c}\text { Araştırma } \\
\text { Tipi }\end{array}$ & Amaç & Örneklem & Girişimler & Değerlendirme \\
\hline 1 & $\begin{array}{l}\text { Barkoukis ve } \\
\text { arkadaşları } \\
(2016) .\end{array}$ & $\begin{array}{l}\text { Yarı } \\
\text { deneysel }\end{array}$ & $\begin{array}{lr}\text { Bu çalışma 16-18 yaş arası } \\
\text { adölesanlarda } & \text { siber } \\
\text { zorbalık } & \text { davranışını } \\
\text { önlemektir. } & \end{array}$ & $\begin{array}{l}\text { Örnekleme dâhil edilen } 500 \\
\text { öğrenciden 355'i katılmıștır. }\end{array}$ & $\begin{array}{l}\text { Kontrol grubunda } 143 \text { ve müdahale } \\
\text { grubunda } 212 \text { öğrencinden } \\
\text { oluşmaktadır. Müdahale olarak } \\
\text { farkındalık eğitimi uygulanmıștır ve } \\
\text { eğitim programı } 8 \text { hafta sürmüștür. } \\
\text { Bu program; posterler, } \\
\text { konferanslar, grup görüşmeleri ve } \\
\text { broșürler șeklinde uygulanmıștır. }\end{array}$ & $\begin{array}{l}\text { Müdahale programı sonrası katılımcıların } \\
\text { empati, ahlaki kavramları ve } \\
\text { bilişsellerinde anlamlı düzeyde } \\
\text { davranış değişikliği } \\
\text { edilmiştir. }\end{array}$ \\
\hline 2 & $\begin{array}{l}\text { Doane ve } \\
\text { arkadaşları } \\
(2016)\end{array}$ & $\begin{array}{l}\text { Yarı } \\
\text { deneysel }\end{array}$ & 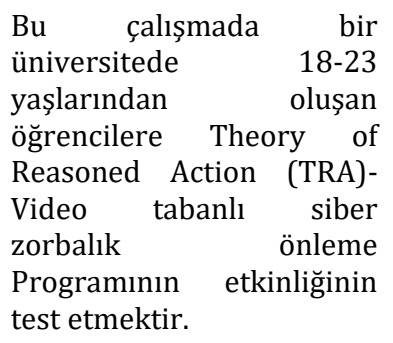 & $\begin{array}{l}\text { Örneklem } 375 \text { öğrenciden } \\
\text { (deney grubunda } 190,185 \\
\text { kontrol grubunda) } \\
\text { oluşmaktadır. } \\
\text { Örneklem tekrardan } 73 \text { kişi } \\
\text { deney grubu, } 94 \text { kişi kontrol } \\
\text { grubu olarak ayrılmıştır. }\end{array}$ & $\begin{array}{l}1 \text { ay süren eğitim programları } \\
\text { sonunda Öğrencilerin Siber } \\
\text { zorbalı bilgisi, Siber Zorbalık } \\
\text { Deneyimleri Anketi, mağdurlara } \\
\text { karşı empati, Tutumlar, ihtiyati } \\
\text { tedbir normları, tanımlayıcı } \\
\text { normları ve niyetler ölçülmüştür. }\end{array}$ & $\begin{array}{l}\text { Müdahale programı sonrası Tutumlarda, } \\
\text { tanımlarda, ihtiyati tedbir normlarının tüm } \\
\text { tiplerinde olumlu değişimler, bilgi } \\
\text { düzeyinde artış, empati olumlu değişim } \\
\text { meydana geldi fakat davranış niyeti hemen } \\
\text { değişmemiştir. }\end{array}$ \\
\hline 3 & $\begin{array}{l}\text { Clarkson ve } \\
\text { arkadaşları } \\
(2016) .\end{array}$ & $\begin{array}{l}\text { Randomize } \\
\text { Kontrollü }\end{array}$ & $\begin{array}{l}\text { Bu çalışmada, ilkokul ve } \\
\text { ortaokullarda KiVA eğitim } \\
\text { programının etkinliğini } \\
\text { değerlendirmektir. }\end{array}$ & $\begin{array}{l}\text { Örneklem, her gruptan } 1070 \\
\text { öğrenci, } 10 \text { okul kontrol ve } \\
10 \text { okul müdahale olmak } \\
\text { üzere } 20 \text { okul seçilerek } \\
\text { oluşturulmuştur. }\end{array}$ & $\begin{array}{l}\text { Kontrol ve Müdahale grubuna KIVA } \\
\text { eğitim programı } 1 \text { yll boyunca } \\
\text { uygulanmıștır. }\end{array}$ & $\begin{array}{l}\text { KIVA eğitim programının okullarda } \\
\text { zorbalı davranışını azaltmada etkili } \\
\text { olduğu tespit edilmiştir. }\end{array}$ \\
\hline 4 & $\begin{array}{l}\text { Cross ve } \\
\text { arkadaşları } \\
(2016)\end{array}$ & $\begin{array}{l}\text { Randomize } \\
\text { Kontrollü }\end{array}$ & $\begin{array}{l}\text { Bu çalışmada The Cyber } \\
\text { Friendly Schools (CFS) } \\
\text { eğitim programının } \\
\text { programının siber zorbalık } \\
\text { davranışının önlemesini } \\
\text { test etmek için } \\
\text { uygulanmıştır. }\end{array}$ & $\begin{array}{l}\text { Örneklem, devlet okulu } \\
\text { olmayan } 35 \text { okul dahil edildi. } \\
\text { Bunların arasından } 19 \\
\text { müdahale ve } 16 \text { kontrol } \\
\text { grubu olarak seçildi. }\end{array}$ & $\begin{array}{l}\text { Öğrenciler } 8 . \text { sınıfın dönem başında } \\
\text { programa alınmıștır. Kontrol } \\
\text { grubunda } 19 \text { okul (1504 öğrenci) } \\
\text { ve Müdahale grubunda } 16 \text { okul } \\
(1878 \text { öğrenci) dahil edilmiştir. } \\
\text { Öğrencilere PRECEDE-PROCEED } \\
\text { modeline göre hazırlanan program } \\
1 \text { yıl boyunca eğitim programı } \\
\text { olarak uygulanmıștır. }\end{array}$ & $\begin{array}{l}\text { Çalışma sonucunda programın siber } \\
\text { zorbalık davranışını uygulama }(\mathrm{P}=.028) \\
\text { ve siber zorbalığa maruz kalma davranışını } \\
(\mathrm{P}=.012) \text { azalttığı tespit edilmiştir }(\mathrm{P}<.05) \text {. } \\
\text { Ayrıca öğretmenlerin programın üçte birini } \\
\text { uyguladığı için etkinliğinin zayı olduğ } \\
\text { tespit edilmiştir. }\end{array}$ \\
\hline 5 & $\begin{array}{l}\text { Salmeron ve } \\
\text { Christian } \\
(2016)\end{array}$ & $\begin{array}{l}\text { Yarı } \\
\text { deneysel }\end{array}$ & $\begin{array}{l}\text { Bu çalışmada } r \text { zorbalık } \\
\text { hakkında okul sağllğı } \\
\text { hemşireleri ve sağlık } \\
\text { asistanı için geliștirilmiş } \\
\text { eğitim programını test }\end{array}$ & $\begin{array}{l}\text { Örneklem } 31 \text { okul hemşiresi } \\
\text { ve } 3 \text { sağlık asistanı olmak } \\
\text { üzere } 34 \quad \text { kişiden } \\
\text { oluşmaktadır. }\end{array}$ & $\begin{array}{l}\text { Zorbalık mağdurlarını rapor etme } \\
\text { ve mağdurlara verilen eğitimin } \\
\text { öncesi ve } \\
\text { değerlendirilmiştir. }\end{array}$ & $\begin{array}{l}\text { Eğitim programının okul hemşirelerinin ve } \\
\text { sağlık asistanı becerilerini artırdığı tespit } \\
\text { edilmiştir. }\end{array}$ \\
\hline
\end{tabular}


Timmons-

Mitchell ve

6 Mitchell ve

(2016).

Yarı

deneysel
$\mathrm{Bu}$ çalışmada, Stand Up

eğitim programının

programının siber zorbalık

davranışını önlemesini Stand Up eğitim programının

test etm
Müdahale çalışması olan pilot çalıșması için 113 lis için öğrencisi dahil edilmiştir.

\begin{tabular}{|c|c|c|c|c|c|c|}
\hline 7 & $\begin{array}{l}\text { Olatunbosun, } \\
(2016)\end{array}$ & $\begin{array}{l}\text { Yarı } \\
\text { deneysel } \\
\text { tasarım }\end{array}$ & $\begin{array}{l}\text { Bu çalışmada, Olweus } \\
\text { eğitim programının } \\
\text { zorbalık davranışı üzerinde } \\
\text { etkisi incelenmektedir. }\end{array}$ & $\begin{array}{lrr}\text { Müdahale } & \text { çalışması yarı } \\
\text { deneysel } & \text { tarzındadır. } \\
\text { Örneklem } & 90 & \text { kişiden } \\
\text { oluşmaktadır. } & & \end{array}$ & $\begin{array}{l}\text { Ortaokul öğrencilerine Olweus } \\
\text { eğitim programı } 6 \text { haftalı seans } \\
\text { șeklinde gerçekleștirilmiştir. } \\
\text { Kontrol grubu } 45 \text { ve müdahale } \\
\text { grubu } 45 \text { kișiden olușmaktadır. }\end{array}$ & $\begin{array}{l}\text { Eğitim Programı sonucu öğrencilerde } \\
\text { zorbalık davranışının etkin bir şekilde } \\
\text { azaldığı tespit edilmiştir. }\end{array}$ \\
\hline 8 & $\begin{array}{l}\text { Gregory ve } \\
\text { arkadasşları } \\
\text { (2016). }\end{array}$ & $\begin{array}{l}\text { Randomize } \\
\text { Kontrollü }\end{array}$ & $\begin{array}{lc}\text { Bu çalışma, } & \text { öğretmen } \\
\text { koçluğu eğitimi } & \text { programı } \\
\text { olan "My } & \\
\text { Teaching } & \text { Partner } \\
\text { Secondary } & \text { (MTP-S)" } \\
\text { zorbalık davranışı üzerinde } \\
\text { etkisi incelenmektedir. }\end{array}$ & $\begin{array}{l}\text { Program örneklemi için } 86 \\
\text { sinıf öğretmeni, öğrencilere } \\
\text { koçluk yapmak için } \\
\text { seçilmiştir. }\end{array}$ & $\begin{array}{l}\text { Eğitim programı } 2 \text { yıl boyunca } \\
\text { devam etmiştir. Kontrol grubu } 39 \\
\text { ve müdahale grubu } 40 \text { kişi } \\
\text { seçilmiştir. Müdahale grubunda } \\
630 \text { öğrenci ve kontrol grubunda } \\
533 \text { öğrenci mevcuttur. }\end{array}$ & $\begin{array}{l}\text { Çalışmada uygulanan eğitim programının } \\
\text { ırksal zorbalı üzerinde etkili olduğu tespit } \\
\text { edilmiştir. Siyah rrka sahip olan } \\
\text { öğrencilerle olmayan öğrenciler arasında } \\
\text { anlamlı bir fark oluşmuştur }(d=0.21) \text {. }\end{array}$ \\
\hline 9 & $\begin{array}{l}\text { Miyazaki ve } \\
\text { arkadaşları } \\
(2016) .\end{array}$ & $\begin{array}{l}\text { Yarı } \\
\text { deneysel }\end{array}$ & 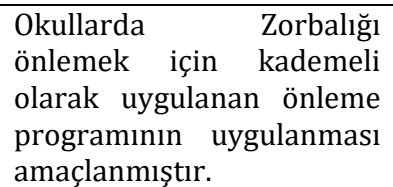 & $\begin{array}{l}22 \text { kız ve } 19 \text { erkek olmak } \\
\text { üzere toplam } 41 \text { kişidir. }\end{array}$ & $\begin{array}{l}\text { Müdahale programı öncesi ön test } \\
\text { ve son test yapılmıștır. } 3 \text { aylık } \\
\text { olmak üzere } 10 \text { seans ve } 15^{\prime} \mathrm{er} \\
\text { dakika sürmüştür. }\end{array}$ & $\begin{array}{l}\text { Erkeklerde müdahale öncesi ve sonrası bir } \\
\text { değişim olmamıştır fakat kızlarda zorbalık } \\
\text { davranışlarında karşı önemli bir değişim } \\
\text { olmuştur. }\end{array}$ \\
\hline 10 & $\begin{array}{l}\text { Midgett ve } \\
\text { Doumas } \\
(2016)\end{array}$ & $\begin{array}{l}\text { Yarı } \\
\text { deneysel }\end{array}$ & $\begin{array}{l}\text { İlkokullarda zorbalık } \\
\text { davranışını önlemek için } \\
\text { uygulanan pilot çalıșmanın } \\
\text { etkinliği incelenmektedir. }\end{array}$ & $\begin{array}{l}\text { Katılımcılar dördüncü ve } \\
\text { altıncı sınıf olmak üzere } 49 \\
\text { kişiden oluşmaktadır. }\end{array}$ & $\begin{array}{l}\text { Müdahale programı öncesi ön test } \\
\text { ve son test yapılmış ve STAC eğitim } \\
\text { programı } 75 \text { dakika sürmüştür. } \\
\text { Eğitim programı r sonucu } \\
\text { öğrencilerin ebeveynlerinden ve } \\
\text { bakıcılarından geri bildirim } \\
\text { alımıștır. }\end{array}$ & $\begin{array}{l}\text { Uygulanan STAC eğitim programı sonucu } \\
\text { öğrencilerde bilgi, davranış ve güven } \\
\text { duygularında olumlu gelişme } \\
\text { edilmiştir. }\end{array}$ \\
\hline 11 & $\begin{array}{l}\text { Newgent ve } \\
\text { arkadaşları } \\
(2016) .\end{array}$ & $\begin{array}{l}\text { Yarı } \\
\text { deneysel }\end{array}$ & $\begin{array}{lr}\text { Bu çalışmada } & \text { zorbalık } \\
\text { türleri, kurbanları ve } \\
\text { problemli } & \text { davranış } \\
\text { arasındaki } & \text { ilişkiyi } \\
\text { inceleyen } & \text { müdahale } \\
\text { çalıșmasıdır. } & \end{array}$ & 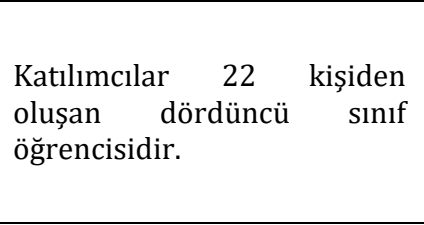 & $\begin{array}{l}\text { Bir ilkokulda öğretmenler } \\
\text { tarafından akran ilişkiler ve sosyal } \\
\text { beceride zorluk çeken } 22 \text { öğrenciye } \\
\text { sosyal beceri ve akran ilişkileri } \\
\text { eğitimi verilmiştir. }\end{array}$ & $\begin{array}{l}\text { Uygulama sonunda öğrencilerde zorbalığı } \\
\text { davranışının bütün türlerinde olumlu } \\
\text { gelişme olduğu tespit edilmiştir. }\end{array}$ \\
\hline
\end{tabular}

Ĕ̆itim programı sonucunda birinci ve üçüncü evre arasında sağlıklı ilişkilerde olumlu yönde, duygusal ve fiziksel zorbalıkta azalıs, duygusal ve fiziksel zorbalık seyircilerde anlamlı değișim tespit edilmiştir. katılımcıdan 88 kişi dahil ve üç aşamada gerçekleştirilmiştir.

Erogramı sonucu öğrencilerde zorbalık davranısının etkin bir sekilde Sçeklinde gerçekleștirilmiştir. grubu 45 kișiden olușmaktadır.

Eğitim programı 2 yll boyunca devam etmistir. Kontrol grubu 39 müdahale grubu 40 kiși mistir. Müdahale grubund 533 öğrenci mevcuttur.

Müdahale programı öncesi ön test ve son test yapılmıştır. 3 aylık dakika sürmüștür. davranıșlarında karșı önemli bir değișim ranıs ve güven duygularında olumlu gelişme tespit ŏgrencilerin ebeveynlerinden ve geri bildirim miștir. gitimi verilmiștir. 


\begin{tabular}{|c|c|c|c|c|c|c|}
\hline 12 & $\begin{array}{l}\text { Ortiz-Bush ve } \\
\text { Schultz } \\
\text { (2016) }\end{array}$ & $\begin{array}{l}\text { Yarı } \\
\text { deneysel }\end{array}$ & $\begin{array}{l}\text { Bu çalışmada, mini bir } \\
\text { konferansla } 13 \text { öğrenciye } \\
\text { zorbalık davranışını } \\
\text { önlemek için video } \\
\text { konferansı ile verilen } 2 \\
\text { günlük bir eğitim programı } \\
\text { incelenmiștir. }\end{array}$ & $\begin{array}{l}\text { Müdahale çalışması olarak } \\
\text { yapplan çalışma } \\
\text { öğrenciden oluşmaktadır. }\end{array}$ & $\begin{array}{l}\text { İki günlük video konferans eğitim } \\
\text { programı } 13 \text { öğrenciye } \\
\text { uygulanmıştır. }\end{array}$ & $\begin{array}{l}\text { Okullardaki zorbalı davranışları } \\
\text { müdahale programları ile uygulanabileceği } \\
\text { tekrardan tespit edilmiştir. }\end{array}$ \\
\hline 13 & $\begin{array}{l}\text { Albayrak ve } \\
\text { arkadaşları } \\
\text { (2016). }\end{array}$ & $\begin{array}{l}\text { Yarı } \\
\text { deneysel }\end{array}$ & $\begin{array}{lr}\text { Okul zorbalık } & \text { önleme } \\
\text { programlarının } & \text { zorbalığın } \\
\text { azaltılması } & \text { üzerindeki } \\
\text { etkisinin } & \\
\text { değerlendirilmesidir }\end{array}$ & $\begin{array}{l}2011-2012 \text { eğitim-öğretim } \\
\text { yllnda İstanbul'daki iki } \\
\text { devlet Illkokulunda öğrencisi } \\
\text { olan } 12-15 \text { yas grubundaki } \\
367 \quad(222 \text { kontrol, } 145 \\
\text { çalışma grubu) öğrenciyle } \\
\text { gerçekleştirilmiştir. } \\
\text { Ornekleme 6. 7. Ve } 8 . \\
\text { Sinnflardan öğrenciler dahil } \\
\text { edilmiștir }\end{array}$ & 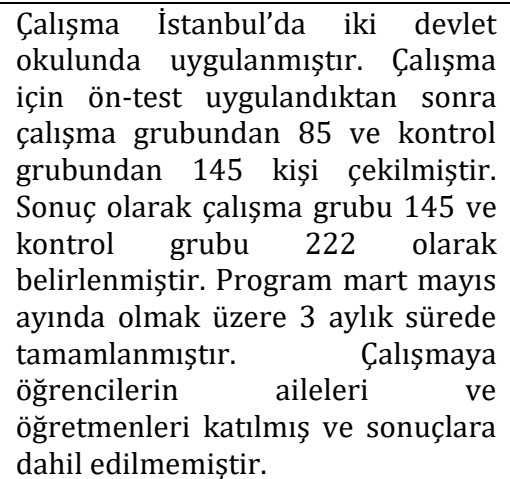 & $\begin{array}{l}\text { Calıssmada Öğrencilerin \%70.3'ü son birkaç } \\
\text { ay içinde zorbalı̆ga uğramadıkları, mağdur } \\
\text { öğrencilerin \%32.1'i durumu kimseye } \\
\text { söylemedikleri, Mağdur olan çocukların } \\
\text { \%37.2'si bir arkadaşına anlattı̆̆l, \%30.1' } \\
\text { ebeveynlerine açıladığ ve \%12.1'inin } \\
\text { durumu sınıf oğretmenlerine açıkladılkları } \\
\text { tespit edilmiştir. Öğrenciler zorbalığa } \\
\text { öğretmen sınıfta yokken, koridorda, } \\
\text { tuvalette ve okul bahçesinde maruz } \\
\text { kaldıklarını belirtmiştir. }\end{array}$ \\
\hline 14 & $\begin{array}{l}\text { Palladino ve } \\
\text { arkadaşları } \\
\text { (2016). }\end{array}$ & $\begin{array}{l}\text { Yarı } \\
\text { deneysel }\end{array}$ & $\begin{array}{lr}\text { Bu çalışmada, "NoTrap!" } \\
\text { eğitim programının siber } \\
\text { zorbalık } & \text { davranışını } \\
\text { önlemede } & \text { etkinliğini } \\
\text { incelemektedir. } & \end{array}$ & 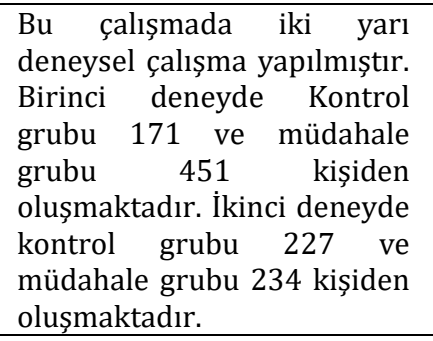 & 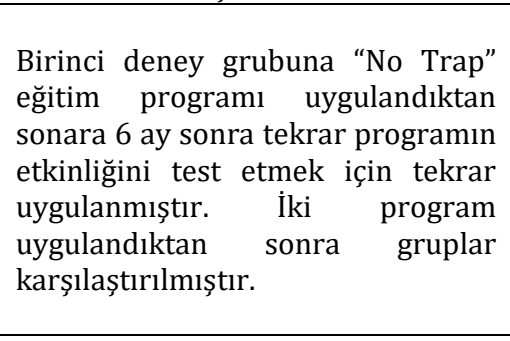 & 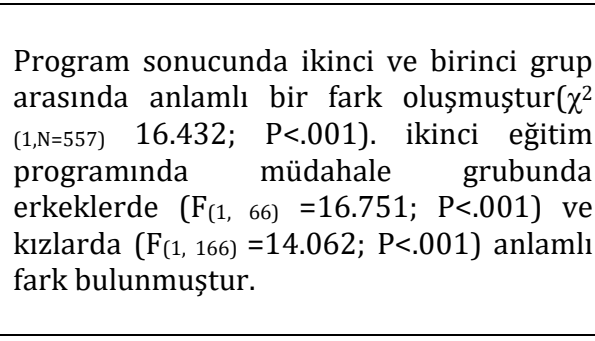 \\
\hline 15 & $\begin{array}{l}\text { Naidoo ve } \\
\text { arkadaşları } \\
\text { (2016). }\end{array}$ & $\begin{array}{l}\text { Randomize } \\
\text { Kontrollü }\end{array}$ & $\begin{array}{l}\text { Okullarda Sözlü zorbalığ } \\
\text { azaltmak için okul temelli } \\
\text { bir eğitim müdahalesini } \\
\text { uygulamaktır. }\end{array}$ & 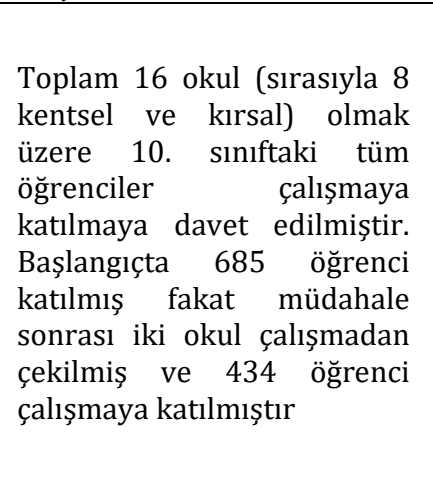 & 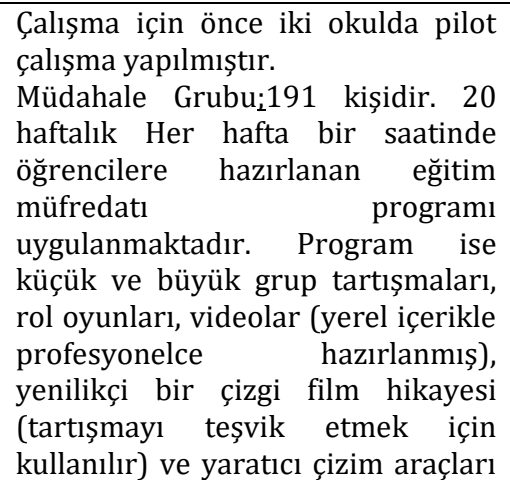 & 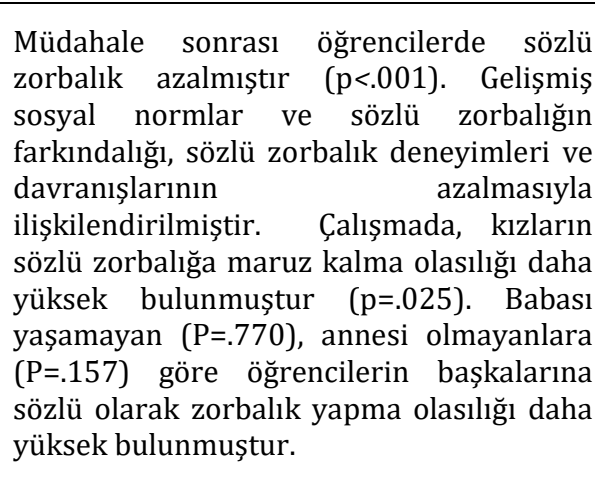 \\
\hline
\end{tabular}




\begin{tabular}{|c|c|c|c|c|c|c|}
\hline & & & & & $\begin{array}{lrrr}\text { uygulanmaktadır. } & & \\
\text { Kontrol } & \text { grubu: } & 243 & \text { kişidir. } \\
\text { Herhangi } & \text { bir } & \text { girişimde } \\
\text { bulunulmamıștir } & \end{array}$ & \\
\hline 16 & $\begin{array}{l}\text { Muratori ve } \\
\text { arkadaşları } \\
\text { (2017). }\end{array}$ & $\begin{array}{l}\text { Randomize } \\
\text { Kontrollü }\end{array}$ & 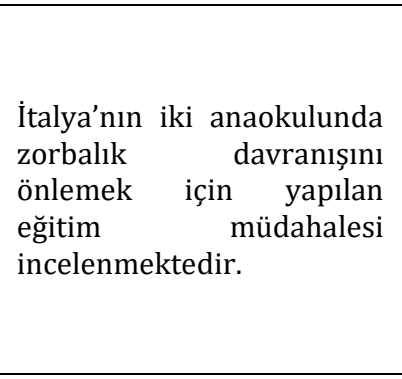 & $\begin{array}{l}\text { İtalyada iki okulun } 10 \text { ana } \\
\text { sinıfını kapsamaktadır ve } \\
164 \text { ögrenci katılmaktadır. }\end{array}$ & $\begin{array}{l}\text { Kontrol grubu ve müdahale grubu } \\
\text { 5'er sinıf olarak ayrılmıstır. } \\
\text { Müdahale sınıfındaki öğretmenler } 6 \\
\text { aylık eğitim programı uygulamıştır. }\end{array}$ & $\begin{array}{l}\text { Yapılan calış̧ada, davranışsal zorluk } \\
\text { puanlarında ögretmenlerde } 0.12 \text { duygusal } \\
\text { problemler, } 0.36 \text { davranısssal problemler, } \\
0.07 \text { Hiperaktif / dikkatsizlik, } 0.08 \text { akran } \\
\text { problemleri ve } 0.03 \text { sosyal yanlı davranış } \\
\text { tespit edilirken ebeveynlerde } 0.09 \\
\text { duygusal problemler, } 38 \text { davranıssal } \\
\text { problemler, } 0.06 \text { Hiperaktif / dikkatsizlik, } \\
0.07 \text { akran problemleri ve } 0.17 \text { sosyal yanlı } \\
\text { davranıșta azalma tespit edilmiștir. }\end{array}$ \\
\hline 17 & $\begin{array}{l}\text { Bonell ve } \\
\text { arkadaşları } \\
\text { (2017). }\end{array}$ & $\begin{array}{l}\text { Randomize } \\
\text { Kontrollü }\end{array}$ & $\begin{array}{lr}\text { Kapsayıcı } & \text { Eğitim } \\
\text { programının } & \text { zorbalık } \\
\text { davranışına } & \text { etkisini } \\
\text { incelemektedir. } & \end{array}$ & $\begin{array}{l}40 \text { devlet okulu ve } 7 . \text { sınıf } \\
\text { öğrencilerinden } \\
\text { olussmaktadır. Okullar tek } \\
\text { cins, karısısı, başarı düzeyi } \\
\text { düşük ve yüksek olarak } \\
\text { randomize edilmiștir. }\end{array}$ & $\begin{array}{l}\text { Sosyal ve duygusal öğgrenme } \\
\text { programı içermektedir. Müdahale } \\
\text { programı ilk iki yll okul idaresi } \\
\text { tarafindan ve üçüncü yll ise okul } \\
\text { dışı belirlenen bir ekip tarafindan } \\
\text { verilecektir. }\end{array}$ & $\begin{array}{l}\text { Uygulanan INCLUSIVE eğitim programının } \\
\text { başarılı olduğu tespit edilmiştir. }\end{array}$ \\
\hline 18 & $\begin{array}{l}\text { Doğan ve } \\
\text { arkadaşları } \\
\text { (2017). }\end{array}$ & $\begin{array}{l}\text { Yarı } \\
\text { deneysel }\end{array}$ & $\begin{array}{l}\text { Bu çalıșmada, ViSC eğitim } \\
\text { programının } \\
\text { incelenmektedir. }\end{array}$ & $\begin{array}{l}\text { Üç okul müdahale ve üç okul } \\
\text { kontrol grubu olarak } \\
\text { seçilmiştir. Toplam } 602 \\
\text { oğrenci katılmıștır. }\end{array}$ & 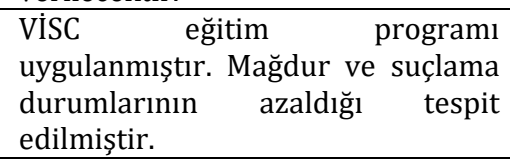 & $\begin{array}{l}\text { Türkiye'de ViSC eğitim programının } \\
\text { gerçeklesstirildiğ ilk çalısmadır. Bu } \\
\text { programın etkinliği sosyal politikalar için } \\
\text { önemlidir. }\end{array}$ \\
\hline 20 & $\begin{array}{l}\text { Healy ve } \\
\text { Sanders } \\
(2017)\end{array}$ & $\begin{array}{l}\text { Yarı } \\
\text { deneysel }\end{array}$ & $\begin{array}{l}\text { Akranları tarafinda } \\
\text { mağduriyete maruz kalan } \\
\text { çocukların depresyonlarını } \\
\text { aile desteği ile tedavi } \\
\text { edilmeye çalışılmıştır. }\end{array}$ & $\begin{array}{l}\text { Yüksek depresyonda olan 6- } \\
12 \text { yaşları arasındaki } 39 \\
\text { çocuğu kapsamaktadır. }\end{array}$ & $\begin{array}{l}\text { Müdahaleden } 6 \text { ay sonra } 26 \text { kişide } \\
\text { depresyon tespit edilmemiştir. } \\
\text { Fakat } 13 \text { kişide depresyon devam } \\
\text { etmektedir. }\end{array}$ & $\begin{array}{l}\text { Zorballk davranışına maruz kalan } \\
\text { çocuklarda bu etkileri azaltmak için aile ve } \\
\text { akran desteğinin önemli olduğu tespit } \\
\text { edilmiștir. Tedaviye dirençli olan } 13 \text { kisininin } \\
\text { aile ve akran desteğine ihtiyaç duyduğu } \\
\text { tespit edilmiștir. }\end{array}$ \\
\hline 21 & $\begin{array}{l}\text { Wang ve } \\
\text { Goldberg } \\
(2017)\end{array}$ & $\begin{array}{l}\text { Yarı } \\
\text { deneysel }\end{array}$ & $\begin{array}{l}\text { Bu çalışmada, The Bullying } \\
\text { Project-Moral } \\
\text { Disengagement }\end{array}$ & $\begin{array}{l}\text { 3. sınıf olmak üzere } 84 \text { kişi } \\
\text { ve öğretmenlerde dahil } \\
\text { edilmiştir. Bir sınıf müdahale }\end{array}$ & $\begin{array}{l}\text { Müdahale sınıfına } 5 \text { hafta eğitim } \\
\text { verilmiştir ve eğitimden } 1 \text { hafta } \\
\text { sonra anket ile değerlendirilmiştir. }\end{array}$ & $\begin{array}{llcc}\text { Calısma } & \text { sonucuna } & \text { göre } & \text { akranların } \\
\text { birbirlerini } & \text { dahi tanıdığı ve öğretmenler } \\
\text { tarafindan } & \text { sosyal geçerliliği olan bir } & \text { olan }\end{array}$ \\
\hline
\end{tabular}


Version (BLP-MD), eğitim $(n=42)$ ve bir sinıf kontrol

programı incelenmektedir. grubu $(\mathrm{n}=42)$ olarak

seçilmiştir. alanlarında artan risk ve

$\begin{array}{lllr}\text { Farmer ve } & \text { Randomize } & \text { zorbalık } & \text { davranışının } \\ \text { arkadaşları } & \text { çocuklar } & \text { arasındak }\end{array}$ 22 arkadaşları (2017)

Randomize etkileşimler etkilemediğini etkileyip/ araștırmaktır.

Okul çağındaki çocuklara yönelik geliștirilen bir yönelik geliștirilen bir girișkenlik üzerindek etkinliğini belirlemektir
Örneklem, 8 kontrol ve 8 müdahale okulu ayrılmıștır. 840 kişi öğrenci $\quad(422$ kontrol) ve ( 418 müdahale), 90 ögretmen (47 kontrol) ve (43 müdahale), ebeveyn (296 kontrol ve 289 müdahale) oluşmaktadır.

\section{Örneklem Ankara'daki}

Çalıșma 2 yll sürmüștür. Müdahale oyun alanlarını yönelik bir program uygulanmıştır.

program olarak değerlendirilmiştir.

Müdahale grubundaki çocukların, kontrol grubuna göre daha fazla mutlu olduğu $(\mathrm{P}=.002)$, müdahale grubu çocukların, kontrol grubuna göre maruz kaldığ zorbalık davranıșını az söylediği $(\mathrm{P}=<.001)$, ebeveynler, 1 yıl içinde çocuklarının zorbalık davranışına maruz kalma durumunu bildirme/bildirmemesinde anlamlı bir fark tespit edilmemis $(P=.07)$. ve müdahale grubundaki öğretmenler 1 yl içinde daha fazla zorbalık davranışı tespit etmiştir $(\mathrm{P}=.009) . \mathrm{Bu}$ çalışmayı ebeveynler desteklemiștir.

\begin{tabular}{|c|c|c|}
\hline 24 & $\begin{array}{l}\text { Midgett ve } \\
\text { arkadaşları } \\
\text { (2018). }\end{array}$ & $\begin{array}{l}\text { Yarı } \\
\text { deneysel }\end{array}$ \\
\hline
\end{tabular}

Okullarda zorbalı̆ğ azaltmak için STAC programının uygulanması amaçlanmıștır.

Bu calışmada Zorbalık olayları sırasında Grassetti ve Yarı bakıcıların tavsiyesi ve 25 Yar (2018). deneysel çocukların seyirci davranıșlarını incelemek amaçlanmiștır.

Rex ve arkadașları 26 (2018).
Otizm

Spektrum

Bozukluğu olan 6 çocuğ uyguladıkları zorbalı davranışını azaltmak amacıyla planlanmıștır. okullardan rastgele seçilmiş 5 ve 6 . Sinıflardan oluşan iki okuldur. $\mathrm{Bu}$ okulların müdahale ve kontrol grubu olması ise okulların isimleri kâğıda yazılarak kura çekilmiştir.

Çalışmada 47 kişi müdahale grubu ve 72 kişi ise kontrol grubunu olusturmaktadır. Müdahale grubuna bir eğitim programı uygulanmıș ve kontrol grubu ile karşılaştırılmıştır.

Calıșmaya 6. sınıf olan $144 \quad 113$ öğrenciye 4 aylık STAC zorbalık öğrenci davet edilmiş fakat 113 öğrenci katılmıștır.

önleme eğitim programı uygulanmıștır.

Sinıf ziyaretleri, akran gözlemleri,

Çalışmaya ilkokul 4. Ve 5.sınıf olan 106 öğrenci dahil edilmiştir.

ziyaretlerinde bakıcıların

tavsiyeleri alınmıștır. Bakıcıların tavsiyeleri çocuklar üzerindeki etkisi değerlendirilmiștir.

Otizm Spektrum Bozukluğu olan 6 çocuğa video yöntemi ile zorbalık

Otizm Spektrum Bozukluğu olan 6 çocuk dahil edilmiștir. cesitleri anlatılmıs ve vido sonrası çocukların edilmiştir.
Yapılan çalıșmada Girișkenlik eğitimi programı atılganlık düzeyini artırdığı ve mağdur olma durumunu azalttığ $ı$, ancak zorba olma durumunu etkilemediği tespit edilmiştir.

\section{Eğitim programının zorbalığı azaltmak için} etkili olduğu bulunmuștur. Ayrica çalışmada öğrencilerde bilgi düzeylerinde ve pozitif davranışlarda olumlu gelişme olmuştur.

Çalıșma sonucunda çocukların bakıcılardan aldıkları tavsiyeler onların okulda zorbalık davranışına etki ettiği bundan dolayı zorbalık davranışını azaltmak için okul-aile iş birliğinin önemine vurgu yapılmaktadır.

Çalışma sonrası 4 çocuk video modelleme yöntemine olumlu cevap verdiği tespit edilmiștir. Bu çalıșma Otizm Spektrum Bozukluğu ile zorbalığa maruz kalanlar açısından tartıșılmıştır. 


\begin{tabular}{|c|c|c|c|c|c|c|}
\hline 27 & $\begin{array}{l}\text { Klippel ve } \\
\text { arkadașları } \\
\text { (2018). }\end{array}$ & $\begin{array}{l}\text { Yarı } \\
\text { deneysel }\end{array}$ & $\begin{array}{l}\text { Bu çalışmada "The Digital } \\
\text { Social Peer Evaluation } \\
\text { Experiment } \\
\text { (Digi-SPEE)" } \\
\text { programını } \\
\text { incelenmektedir. }\end{array}$ & $\begin{array}{l}\text { Sağllklı olarak seçilen } 708 \\
\text { ergen müdahaleye dahil } \\
\text { edilmiştir. Her seansta kişi } \\
\text { sayısı 354'tür. }\end{array}$ & $\begin{array}{l}\text { Uygulama } 2 \text { seansta } \\
\text { gerçekleşmektedir. İlk seansta } \\
\text { katılımcılardan kendilerini tanıtan } \\
\text { bir video, yazılı profil } \\
\text { oluşturmalarını ve başka bir video } \\
\text { ve yazılı belgeyi puanlamaları } \\
\text { istenmiştir. ikinci seansta kendi } \\
\text { profillerini ve vidolarını izlemeleri } \\
\text { sağlanmıștır. }\end{array}$ & $\begin{array}{l}\text { Ergenler arasında zorbalık davranışının } \\
\text { değerlendirmesinde çevrenin etkili olduğu } \\
\text { tespit edilmiştir. Geçmişte ve öznel sosyal } \\
\text { durumların akran zorbalı davranışını } \\
\text { etkilediği belirtilmiștir }\end{array}$ \\
\hline 28 & $\begin{array}{l}\text { Yokoo ve } \\
\text { arkadaşları } \\
(2018)\end{array}$ & $\begin{array}{l}\text { Yarı } \\
\text { deneysel }\end{array}$ & \begin{tabular}{lrr} 
İlkokul & \multicolumn{2}{r}{ ögrencilerinde } \\
video tabanlı & zorbalık \\
davranışını & önlemek \\
amacıyla geliştirilmiştir
\end{tabular} & $\begin{array}{l}\text { Müdahale grubu } 168 \text { ve } \\
\text { kontrol grubu } 169 \text { olarak } \\
\text { belirlenmiștir. }\end{array}$ & $\begin{array}{l}\text { İlkokul 4. 5. Ve 6. Sınıf öğrencilerine } \\
30 \text { dk viode programı öğrencilerin } \\
\text { dikkatini çekmek için } 10 \mathrm{dk}{ }^{\prime} l \mathrm{k} \\
\text { olarak üç bölümde izletilmiştir. }\end{array}$ & $\begin{array}{l}\text { Çalışmada öğrencilerin bilgi düzeyinin } \\
\text { arttığı tespit edilmiştir fakat sürdürülebilir } \\
\text { bir program geliştirilmesi tavsiye } \\
\text { edilmiştir. }\end{array}$ \\
\hline 29 & $\begin{array}{l}\text { Hie Song ve } \\
\text { arkadaşları } \\
\text { (2018). }\end{array}$ & $\begin{array}{l}\text { Yarı } \\
\text { deneysel }\end{array}$ & $\begin{array}{l}\text { Bu çalışmada, öğretmenleri } \\
\text { zorbalık davranıșına karşı } \\
\text { pasif veya aktif müdahale } \\
\text { etmesine sağlayan bireysel } \\
\text { ve çevresel faktörleri } \\
\text { incelemiștir. }\end{array}$ & $\begin{array}{lrl}\text { Müdahale } & \text { grubu } & 200 \\
\text { öğretmen katılmıştır. } & \end{array}$ & $\begin{array}{l}\text { Öğretmenlere } 1 \text { saat eğitim } \\
\text { programı uygulanmıştır. }\end{array}$ & $\begin{array}{l}\text { Çalışma sonucuna göre pasif öğretmenlerin } \\
\text { okul idaresi tarafından desteklenmesi } \\
\text { gerektiği ve aktif öğrencilerin ise } \\
\text { meslektaşlarından destek görmesi } \\
\text { gerektiği belirtilmiştir. }\end{array}$ \\
\hline 30 & $\begin{array}{l}\text { Rana ve } \\
\text { arkadaşları } \\
\text { (2018). }\end{array}$ & $\begin{array}{l}\text { Yarı } \\
\text { deneysel }\end{array}$ & $\begin{array}{l}\text { Bu çalışmada, Kuzey } \\
\text { Hindistan, Chandigarh'daki } \\
\text { ergenler arasında zorbalığl } \\
\text { azaltmak için çok bileşenli } \\
\text { okul tabanlı bir } \\
\text { müdahalenin etkinliği } \\
\text { incelenmektedir. }\end{array}$ & $\begin{array}{l}\text { Toplam } 846 \text { olan } 7 . \text { Ve } 8 . \\
\text { Sinıf öğrencileri } 425 \text { kontrol } \\
\text { ve } 421 \text { müdahale grubu } \\
\text { olarak ayrılmıștır. }\end{array}$ & $\begin{array}{l}\text { Müdahale öğrencilerin kendi } \\
\text { aralarındaki ilişki, ebeveyn ve } \\
\text { öğretmenlerle olan ilişkisi, okul } \\
\text { tabanlı ilişkiye dair müdahale } \\
\text { uygulanmıştır. }\end{array}$ & $\begin{array}{l}\text { Bu program, okul yöneticilerini, } \\
\text { öğretmenleri ve ebeveynleri kapsadı̆̆ için } \\
\text { bütün okul tabanlı } \text { müdahale } \\
\text { programlarından farklıdır. Bu program, } \\
\text { düşük ve orta gelirli ülkelere rehberlik } \\
\text { edebilir. }\end{array}$ \\
\hline 31 & $\begin{array}{l}\text { Akcan ve } \\
\text { Ergün (2019) }\end{array}$ & $\begin{array}{l}\text { Yarı } \\
\text { deneysel }\end{array}$ & $\begin{array}{lr}\text { Agresif davranış } & \text { önleme } \\
\text { programının } & \text { anaokulu } \\
\text { öğrencileri } & \text { üzerindeki } \\
\text { etkisi } & \end{array}$ & $\begin{array}{l}\text { Calışma, bir } \text { ilkokul } \\
\text { anaokuluna kayıtlı } 90 \text { çocuk } \\
\text { (müdahale grubu }=45, \\
\text { kontrol grubu = 45) ile } \\
\text { gerçekleştirilmiştir. }\end{array}$ & $\begin{array}{l}\text { Eğitim programı } 12 \text { hafta boyunca } \\
\text { çocuklar ve } \begin{array}{l}\text { aileleri ile } \\
\text { uygulanmıştır. }\end{array}\end{array}$ & $\begin{array}{l}\text { Anaokulu öğrencileri arasında saldırganlık } \\
\text { düzeylerini önemli ölçüde azaldığı tespit } \\
\text { edilmiştir. Türkiye'de okulda çalışan bir } \\
\text { hemşire tarafından yapılan ilk çalışmadır } \\
\text { ve hemşirelerin uygulama ve } \\
\text { araştırmalarına örnek olması açısından } \\
\text { önem arz etmektedir. }\end{array}$ \\
\hline 32 & $\begin{array}{l}\text { Fischer ve Bilz } \\
(2019)\end{array}$ & $\begin{array}{l}\text { Yarı } \\
\text { deneysel }\end{array}$ & $\begin{array}{lr}\text { Öğretmenlerin } & \text { zorbalık } \\
\text { müdahalelerinde } & \text { öz- } \\
\text { yeterlikleri ve müdahale } \\
\text { olasılıkları }\end{array}$ & $\begin{array}{l}\text { Müdahale grubu } 24 \text { okuldan } \\
556 \text { öğretmen katılmıștır. }\end{array}$ & $\begin{array}{ll}\text { Öğretmenlerin } & \text { öz-yeterliliklerinin } \\
\text { artırılmasına } & \text { yönelik eğitim } \\
\text { verilmiştir. } & \end{array}$ & 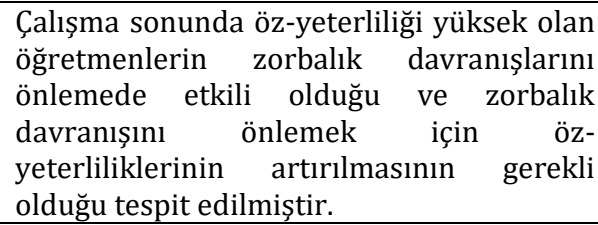 \\
\hline
\end{tabular}




\begin{tabular}{|c|c|c|c|c|c|c|}
\hline 33 & $\begin{array}{l}\text { Costantino ve } \\
\text { arkadaşları } \\
\text { (2019). }\end{array}$ & $\begin{array}{l}\text { Yar1 } \\
\text { deneysel }\end{array}$ & $\begin{array}{lcr}\text { İtalya'nın bir } & \text { şehrinde } \\
\text { ortaokullarda } & \text { zorbalığı } \\
\text { azaltmak için } & \text { yapılan } \\
\text { müdahale } & & \\
\end{array}$ & 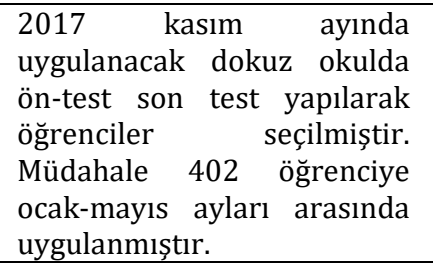 & $\begin{array}{l}\text { Öğrencilere } 5 \text { ay süresince özel } \\
\text { etkinlikler düzenlenerek zorbalık } \\
\text { hakkındaki davranışları azaltılmaya } \\
\text { çalışılmışıtır. }\end{array}$ & $\begin{array}{l}\text { Yapılan çalışma sonucunda zorbalı̆̆ın } \\
\text { bütün türlerinde azalma olduğu tespit } \\
\text { edilmiștir. Özellikle orta sosyoekonomik } \\
\text { düzeydeki okullara devam ögrencilerde } \\
\text { zorbalık davranısıınn anlamlı derecede } \\
\text { azaldığı tespit edilmiştir. }\end{array}$ \\
\hline 34 & $\begin{array}{l}\text { Bowes ve } \\
\text { arkadaşları } \\
(2019) \text {. }\end{array}$ & $\begin{array}{l}\text { Yar1 } \\
\text { deneysel }\end{array}$ & $\begin{array}{lr}\text { Endonezya'da } & \text { Ortaokul } \\
\text { öğrencilerinde } & \text { zorbalık } \\
\text { davranışını önlemek için } \\
\text { gelisstirilen } & \text { eğitim } \\
\text { programının } & \text { pilot } \\
\text { çalış̧masını } & \text { incelemesi } \\
\text { amaçlanmıștır. } & \\
\end{array}$ & $\begin{array}{l}\text { Birinci pilot çalışmada } 2.075 \\
\text { öğrenciden veri toplanmıştır. } \\
\text { İkinci pilot çalsşmada } 5.517 \\
\text { öğrenciden veri toplanarak } \\
\text { randomize kontrollü bir } \\
\text { çalışma yapılmıştır. }\end{array}$ & $\begin{array}{l}\text { Öğrenci odaklı ve öğrenmelerin öz } \\
\text { yeterliliklerini artırmak amaciyla } \\
\text { tasarlanan Roots Eğitim programı } \\
\text { uygulanmıştır. }\end{array}$ & $\begin{array}{l}\text { Roots Eğitim programı kabul edilebilir ve } \\
\text { uygulanabilir olduğu test edilmiștir. } \\
\text { Çalışma sonucunda programın etkililiğini } \\
\text { ve maliyet etkinliğini incelemek için tam } \\
\text { randomize kontrollü bir çalışmaya gerekli } \\
\text { olduğu tespit edilmişstir. }\end{array}$ \\
\hline 35 & $\begin{array}{l}\text { Vives-Cases } \\
\text { ve arkadaşları } \\
\text { (2019). }\end{array}$ & $\begin{array}{l}\text { Yar1 } \\
\text { deneysel }\end{array}$ & $\begin{array}{lr}\text { Ergenlerin } & \text { akranlarıyla } \\
\text { olumlu } & \text { ilişkiler } \\
\text { geliştirmeye yönelik güçlü } \\
\text { yönlerine ve yeteneklerine } \\
\text { odaklanan flört şiddetini } \\
\text { önlemek için kanıta dayalı } \\
\text { stratejilererratkıda } \\
\text { bulunmaktır. }\end{array}$ & 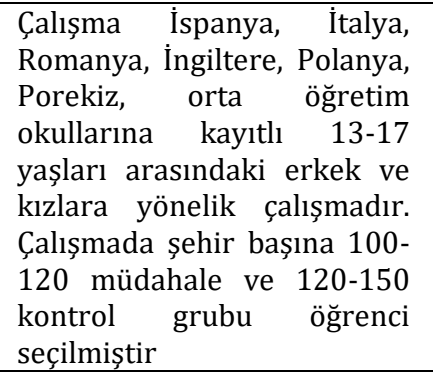 & $\begin{array}{l}\text { Müdahale Grubuna: } \text { Öğrencilere } \\
\text { toplam beş modül, yaklaşı } 50 \\
\text { dakikalı } 15 \text { ila } 17 \text { seans } \\
\text { gerçekleştirilmiştir. Çalışma toplam } \\
24 \text { ay sürmüştür. } \\
\text { Kontrol Grubu: Müdahale grubu ile } \\
\text { aynı sosyal özelliklere sahip } \\
\text { okullardan } \\
\text { oluşacaktır }\end{array}$ & 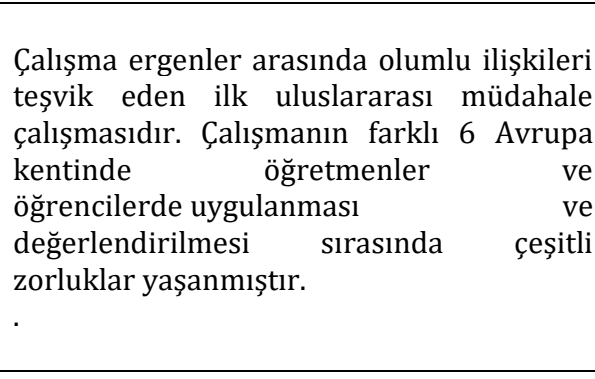 \\
\hline 37 & $\begin{array}{l}\text { Doumas ve } \\
\text { arkadassları } \\
\text { (2019). }\end{array}$ & $\begin{array}{l}\text { Randomize } \\
\text { Kontrollü }\end{array}$ & \begin{tabular}{lrr} 
Zorbalık davranışının & \multicolumn{2}{c}{ dçres } \\
önlenmesi için & "STAC \\
program" isimli eğitim \\
programının incelenmesi \\
amaçlanmaktadır
\end{tabular} & $\begin{array}{l}\text { Örneklem } 65 \text { lise öğrencisi } \\
\text { oluşturmaktadır. Müdahale } \\
\text { grubu } 31 \text { ve kontrol grubu } \\
34 \text { ögrenciden oluşmaktadır. }\end{array}$ & $\begin{array}{l}\text { Eğitim programı } 90 \text { dakika } \\
\text { sürmüștür. }\end{array}$ & $\begin{array}{l}\text { Yapılan çalışma sonucunda müdahale ve } \\
\text { kontrol grubu arasinda bilgi }(\mathrm{P}<0.001) \text { ve } \\
\text { güven }(\mathrm{P}<0.001) \text { düzeyinde anlamlı fark } \\
\text { tespit edilmiştir. Ayrıca programın lise } \\
\text { düzeyindeki öğrencilerde kullanılması } \\
\text { tartışılmaktadır. }\end{array}$ \\
\hline 38 & $\begin{array}{l}\text { Federici ve } \\
\text { arkadaşları } \\
\text { (2019). }\end{array}$ & $\begin{array}{l}\text { Randomize } \\
\text { Kontrollü }\end{array}$ & 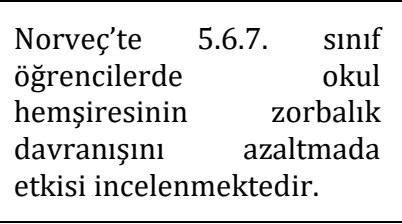 & $\begin{array}{l}\text { Norveç'te } 12 \text { belediyeye ait } \\
107 \text { okuldan yaklaşık } 9000 \\
\text { öğrenci her belediyeden dört } \\
\text { okul seçilmiş ve okullardaki } \\
\text { hemşireler dahil edilmiştir. }\end{array}$ & $\begin{array}{l}\text { Hemşirelerin zorbalık davranışına } \\
\text { etkileri }\end{array}$ & $\begin{array}{l}\text { Okul hemşresi olan okullarda, öğrencilerin } \\
\text { akademik performansı ( } \mathrm{p}<0.05) \text {, okula } \\
\text { uyum hali }(\mathrm{p}<0.05) \text {, okula aidiyet duygusu } \\
(\mathrm{p}<0.05), \text { oggrencilerin derse katllımı } \\
(\mathrm{p}<0.05), \text { benlik kavramı }(\mathrm{p}<0.05), \\
\text { motivasyon ve okula devamsizlığı }\end{array}$ \\
\hline
\end{tabular}




\begin{tabular}{|c|c|c|c|c|c|c|}
\hline 39 & $\begin{array}{l}\text { Gouveia ve } \\
\text { arkadaşları } \\
(2019) .\end{array}$ & $\begin{array}{l}\text { Yarı } \\
\text { deneysel }\end{array}$ & $\begin{array}{l}\text { Bu çalışmada, "The Student } \\
\text { and Family Office (SFO)" } \\
\text { modelinin zorbalık } \\
\text { davranışı hakıkında etkisi } \\
\text { incelenmektedir. }\end{array}$ & $\begin{array}{l}132 \quad \text { Portekizli } \\
\text { oluşturmaktadır. }\end{array}$ & $\begin{array}{l}132 \text { Portekizli ergene iki evrede } \\
\text { uygulanmıştır. İlk evrede } 7 \text {. ve } 8 . \\
\text { Sınıflar oluşturmaktadır. İkinci } \\
\text { evrede 7. 8. 9. 10. Sinıflar yer } \\
\text { almaktadır. }\end{array}$ & $\begin{array}{l}\text { Eğitim programı sonuçlarına göre } \\
\text { saldırganlı, mağduriyet azalmış ve } \\
\text { kissilerarası ilișkiler ve sosyal beceri } \\
\text { düzeyleri artmıstır. }\end{array}$ \\
\hline 40 & $\begin{array}{l}\text { Hormazábal- } \\
\text { Aguayo ve } \\
\text { arkadașları } \\
\text { (2019). }\end{array}$ & $\begin{array}{l}\text { Randomize } \\
\text { Kontrollü }\end{array}$ & $\begin{array}{lr}\text { Bu çalıșma "The } & \text { Active- } \\
\text { Start" dezavantajlı gruplar } \\
\text { arasında zorbalık davranıșı } \\
\text { hakkındararis } \\
\text { incelenmektedir. }\end{array}$ & $\begin{array}{l}\text { Şili'de devlet okulunda } 3 \\
\text { devlet okulunda toplam } 170 \\
\text { ortaokul ögrrencisi } \\
\text { katılmıştır. Müdahale grubu } \\
88 \text { ve kontrol grubu } 58 \text { kiși } \\
\text { olarak belirlenmiştir. }\end{array}$ & $\begin{array}{l}\text { The Active-Start eğitim programı } \\
\text { okul öncesi } \\
\text { uygulangrencilere } \\
\text { Müdahale grubuna spor Oyunları, } \\
\text { oyun alanı oyunları, dans ve diğer } \\
\text { eğlence etkinlikleri uygulanmıștır. }\end{array}$ & $\begin{array}{l}\text { Çalışma sonucunda fiziksel }(\mathrm{OR}=0.18,95 \% \\
\mathrm{CI}, 0.04-0.82 ; \mathrm{p}=.027) \text { ve sözel }(\mathrm{OR}=0.13 \text {, } \\
95 \% \mathrm{CI}, 0.02-0.97 ; \mathrm{p}=.046) \text { zorbalıkta } \\
\text { azalma tespit edilmiştir. }\end{array}$ \\
\hline 41 & $\begin{array}{l}\text { Huitsing ve } \\
\text { arkadaşları } \\
\text { (2019). }\end{array}$ & $\begin{array}{l}\text { Randomize } \\
\text { Kontrollü }\end{array}$ & $\begin{array}{l}\text { Bu çalışmada, ilkokul ve } \\
\text { ortaokullarda KiVA eğitim } \\
\text { programının } \text { etkinliğini } \\
\text { değerlendirmek } \\
\text { yapılmıştır }\end{array}$ & $\begin{array}{l}2954 \text { öğrenci müdahale } \\
\text { grubunda ve } 1402 \text { öğrenci } \\
\text { kontrol grubunda yer } \\
\text { almaktadır. }\end{array}$ & $\begin{array}{l}1 \text { yıl uygulanan KiVA eğitim } \\
\text { programında öğrencilerin okul } \\
\text { iyilik düzeyi, öz yeterlilik, sosyal } \\
\text { anksiyete yönleri ve depresyon } \\
\text { yönleri değerlendirilmiştir. }\end{array}$ & $\begin{array}{l}\text { Yapılan çalışmada depresif belirtisi }(\mathrm{M}= \\
0.64, \mathrm{SD}=0.53), \text { Sosyal anksiyete }(\mathrm{M}=0.94 \text {, } \\
\mathrm{SD}=0.76), \text { Öz saygı }(\mathrm{M}=3.07, \mathrm{SD}=0.83) \text { ve } \\
\text { okul iyilik hali }(\mathrm{M}=2.10, \mathrm{SD}=0.57) \text { tespit } \\
\text { edilmiştir. Müdahale genel olarak başarll } \\
\text { bulunmuştur fakat kontrol grubundakiler } \\
\text { müdahale grubuna göre daha fazla depresif } \\
\text { belirti ve düşük benlik saygısı olduğu tespit } \\
\text { edilmiștir. Zorbalık davranıșında en çok } \\
\text { çevrenin etkili olduğu belirtilmiștir. }\end{array}$ \\
\hline 42 & $\begin{array}{l}\text { Van Ryzin ve } \\
\text { Roseth (2019) }\end{array}$ & $\begin{array}{l}\text { Randomize } \\
\text { Kontrollü }\end{array}$ & $\begin{array}{lr}\text { Bu çalışma } & \text { ortaokullarda } \\
\text { işbirlikçi } & \text { öğrenme } \\
\text { yönteminin } & \text { zorbalık } \\
\text { davranışı üzerinde etkisi } \\
\text { beklenmektedir. }\end{array}$ & $\begin{array}{l}\text { Örneklem } 7 . \text { ve } 8 . \quad \text { Sınıf } \\
\text { öğrencilerden olușmaktadır. } \\
\text { Müdahale grubunda } 875 \\
\text { öğrenci ve } 1015 \text { öğrenci } \\
\text { kontrol grubundadır. } \\
\end{array}$ & $\begin{array}{l}\text { Hafta } 1,5 \text { günlük video-konferans } \\
\text { ile eğitim verilmektedir ve düzenli } \\
\text { olarak takip yapılmaktadır. }\end{array}$ & $\begin{array}{l}\text { Çalışma sonuncunda eğitim programının } \\
\text { öğrencilerin empati }(\mathrm{p}<.05) \text { ve akran } \\
\text { ilisskilerine olumlu }(\mathrm{p}<.05) \text { etki ettiği tespit } \\
\text { edilmiștir. }\end{array}$ \\
\hline 43 & $\begin{array}{l}\text { Wo'jcik ve } \\
\text { Hełka (2019) }\end{array}$ & $\begin{array}{l}\text { Yarı } \\
\text { deneysel }\end{array}$ & $\begin{array}{l}\text { Bu çalışmada The ABBL } \\
\text { eğitim programının } \\
\text { etkinliğini değerlendirmek } \\
\text { amacıyla yapılmıştır }\end{array}$ & $\begin{array}{lr}\text { Örneklemi } 96 & \text { ortaokul } \\
\text { öğrencisi } & \text { kişi } \\
\text { olussturmaktadır. } & \\
\text { Öğrencilerin 53'ü kontrol ve } \\
\text { 43'ü müdahale grubundadır. } \\
\end{array}$ & $\begin{array}{l}\text { Eğitim programı } 11 \text { hafta } \\
\text { öğretmenler } \\
\text { uygulanmıștır. }\end{array}$ & $\begin{array}{l}\text { Çalışma sonuncunda eğitim programının } \\
\text { öğrencilerde zorbalık davranışını azalttığı } \\
\text { belirtilmiştir. }\end{array}$ \\
\hline 44 & $\begin{array}{l}\text { Saınıo ve } \\
\text { arkadaşları } \\
(2020) .\end{array}$ & $\begin{array}{l}\text { Yarı } \\
\text { deneysel }\end{array}$ & $\begin{array}{l}\text { Bu çalışma Finlandiya'da } \\
\text { ilkokulda uygulanan KIVA } \\
\text { eğitim } \\
\text { incelenmiștir. }\end{array}$ & $\begin{array}{l}\text { İlk başta } 1771 \text { okula alınmış } \\
\text { ve en son } 956 \text { okula } \\
\text { uygulanmıştır. }\end{array}$ & $\begin{array}{l}\text { Okullarda uygulanan KiVA eğitim } \\
\text { programı }\end{array}$ & $\begin{array}{l}\text { Çalışma sonucuna göre KIVA eğitim } \\
\text { programının etkinliği büyük okullarda } \\
\text { küçük okullara nispeten etkinliğinin daha } \\
\text { çok devam ettiği tespit edilmiştir. }\end{array}$ \\
\hline 45 & Zambuto ve & Yarl & çalışmada, & Örneklem 118 öğrenciden & 524 öğrenciye anket uygulaması & Çalıșma sonuncunda eğitim programının \\
\hline
\end{tabular}




\begin{tabular}{|c|c|c|c|c|c|c|}
\hline & $\begin{array}{l}\text { arkadaşları } \\
\text { (2019). }\end{array}$ & deneysel & $\begin{array}{l}\text { Ĕgitim programı liseli } \\
\text { öğrencilerde incelenmiştir. }\end{array}$ & oluşturmaktadır. & 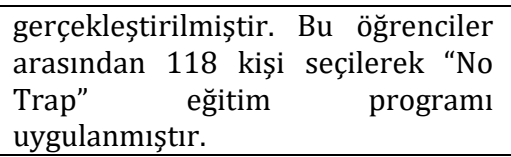 & $\begin{array}{l}\text { öğrencilerde zorbalık davranışını azalttığı } \\
\text { belirtilmiştir. }\end{array}$ \\
\hline 46 & $\begin{array}{l}\text { Clarkson ve } \\
\text { arkadaşları } \\
\text { (2019). }\end{array}$ & $\begin{array}{l}\text { Yarı } \\
\text { deneysel }\end{array}$ & $\begin{array}{l}\text { Bu çalışma, İngiltere'de } \\
\text { KIVA eğitim programının } \\
41 \text { ilkokulda } r \text { zorbalık } \\
\text { davranışına ve maliyet } \\
\text { yönünden } \\
\text { değerlendirilmiștir. }\end{array}$ & $\begin{array}{l}\text { Örneklem } 41 \text { ilkokulun } \\
\text { tamamı dahil edilmiştir. } \\
\text { Yapılan çalışmada ön test- } \\
\text { son test yapılmıștır. }\end{array}$ & $\begin{array}{l}\text { Öğrencilere zorbalığa karşı durma, } \\
\text { mağdurları destekleme, saygı gibi } \\
\text { konular iki hafta bir olmak üzere } 45 \\
\text { dakikalık dersler } 10 \text { ay boyunca } \\
\text { öğrencilere ders verilmiştir. }\end{array}$ & $\begin{array}{l}\text { Yapılan çalışma sonunda mağdurların ön } \\
\text { testte oranı \%18.1iken son testte \%15,7'e } \\
\text { düşmüş ve zorbalık davranışlarında azalma } \\
\text { saptanmıştır. Ayrıca KiVA eğitim } \\
\text { programının okulara maliyet yönünden } \\
\text { faydası incelenmiştir. }\end{array}$ \\
\hline 47 & $\begin{array}{l}\text { Karataş ve } \\
\text { Öztürk (2020) }\end{array}$ & $\begin{array}{l}\text { Yarı } \\
\text { deneysel }\end{array}$ & $\begin{array}{lr}\text { İlkokullarda } & \text { zorbalığa } \\
\text { karșı geliștirilen bir } \\
\text { programın } & \text { etkisinin } \\
\text { incelenmesi } & \end{array}$ & $\begin{array}{lcr}\text { Calışmaya } & \text { izmir } & \text { ilinin } \\
\text { Karabağlar } & \text { ve } & \text { konak } \\
\text { ilçesinden rastgele seçilen iki } \\
\text { okulda toplam } & 135 & \text { öğrenciye } \\
\text { uygulanmıştır }\end{array}$ & $\begin{array}{l}\text { Deney grubundaki, } \\
\text { zorbalığgrencilere } \\
\text { önleme }\end{array} \begin{array}{r}\text { programı } \\
\text { uygulanmıștır ayrıca ebeveynler ve } \\
\text { ögretmenler } 5 \text { hafta boyunca } \\
\text { eğitime katılmıştır. }\end{array}$ & $\begin{array}{l}\text { Yapılan çalıșma mağdurlarda } 1 . \text { yılın } \\
\text { sonuna kadar devam ettiği bulunmuştur; } \\
\text { ancak, 1. yılın sonuna kadar zorbalarda } \\
\text { eğitimin etkinliği azalmaktadır. }\end{array}$ \\
\hline 48 & $\begin{array}{l}\text { Ye ve } \\
\text { arkadaşları } \\
(2020)\end{array}$ & $\begin{array}{l}\text { Yarı } \\
\text { deneysel }\end{array}$ & $\begin{array}{l}\text { Video Tabanlı DT - SVM } \\
\text { Okul Şiddeti Algllama } \\
\text { Algoritma Eğitim programı } \\
\text { incelenmiştir. }\end{array}$ & $\begin{array}{l}\text { Programın etkinliğini test } \\
\text { etmek amaciyla birkaç } \\
\text { gönüllü üzerinde yapılmıștır. }\end{array}$ & 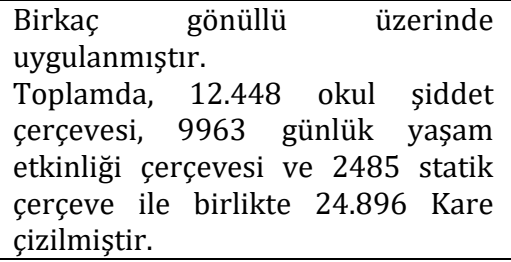 & $\begin{array}{l}\text { Uygulanan eğitim programının gençlerde } \\
\text { zorbalı davranışını azaltmada etkili } \\
\text { olduğu tespit edilmiştir. }\end{array}$ \\
\hline 49 & $\begin{array}{l}\text { Shinde ve } \\
\text { arkadaşları } \\
(2020)\end{array}$ & $\begin{array}{l}\text { Randomize } \\
\text { Kontrollü }\end{array}$ & $\begin{array}{lr}\text { Bu çalışma } & \text { Hindistan'da } \\
\text { okullarda } & \text { zorbalık } \\
\text { davranışını } & \text { önlemek } \\
\text { amacıyla } & \text { "SEHER" isimli } \\
\text { eğitim } & \text { programının } \\
\text { incelenmektedir. }\end{array}$ & $\begin{array}{l}\text { Kontrol grubunda } 25 \text { okul } \\
\text { müdahale grubunda } 49 \text { okul } \\
\text { yer almaktadır. }\end{array}$ & 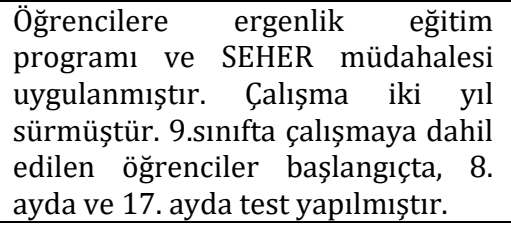 & $\begin{array}{l}\text { Çalışmada öğretmenlere klyasla okulun } \\
\text { ekip üyesi olmayan biri tarafindan verilen } \\
\text { eğitimin daha etkili olduğu tespit } \\
\text { edilmiştir. }\end{array}$ \\
\hline 50 & $\begin{array}{l}\text { Van } \\
\text { Niejenhuisi } \\
\text { ve arkadaşları } \\
(2020) \text {. }\end{array}$ & $\begin{array}{l}\text { Randomize } \\
\text { Kontrollü }\end{array}$ & $\begin{array}{l}\text { Bu çalışma ebeveyn-okul iş } \\
\text { birliği sağlanarak zorbalık } \\
\text { davranışını önlemek için } \\
\text { KivA eğitim programı } \\
\text { uygulanmıştır. }\end{array}$ & $\begin{array}{l}\text { Calışmada örneklem } 13 \\
\text { müdahale ve } 14 \text { kontrol } \\
\text { okulundan öğretmenler }=83 \text {, } \\
\text { ebeveynler }=153 \text {, çocuklar }= \\
2,510 \text { kişiden oluşmaktadır. }\end{array}$ & $\begin{array}{lcr}\text { Çalışmada } & 3-6 \text { sınıf } & \text { öğrencilerine } \\
\text { KivA } & \text { Eğitim } & \text { Programı } \\
\text { uygulanmıștır ve iki } & \text { aşamada } \\
\text { gerçekleştirilmiştir. } & & \end{array}$ & $\begin{array}{l}\text { Bu çalışma ebeveynlerin rolünü sistematik } \\
\text { olarak ortaya koyan ilk çalışmadır. } \\
\text { Ebeveyn (p<0.10.) ve okul yöneticilerin } \\
(p<0.10 \text {.) etkilerini değerlendirmek için } \\
\text { uzun vadede çalışmalara ihtiyaç olduğu } \\
\text { tespit edilmiştir. }\end{array}$ \\
\hline 51 & $\begin{array}{l}\text { Olweus ve } \\
\text { arkadaşları } \\
(2020) .\end{array}$ & $\begin{array}{l}\text { Yarı } \\
\text { deneysel }\end{array}$ & $\begin{array}{l}\text { Bu çalışmada, OLWEUS } \\
\text { eğitim programının uzun } \\
\text { ylllara olan etkinliğini } \\
\text { incelemektedir. }\end{array}$ & $\begin{array}{ll}\text { 1-7 sinıflardan } & \text { oluşan } 234 \\
\text { öğrenci } & \text { örneklemi } \\
\text { oluşturmaktadır. } & \end{array}$ & $\begin{array}{l}\text { Öğrencilere OLWEUS } \\
\text { programı uygulanmıștır. }\end{array}$ & $\begin{array}{l}\text { Uygulama etkinliğinde } 1-2 \text { yll sonra ve } \\
\text { tekrar } 4 \text { yll sonra değerlendirildiğinde } \\
\text { OLWEUS eğitim programının etkin olduğu } \\
\text { tespit edilmiștir. }\end{array}$ \\
\hline
\end{tabular}




\section{EXTENDED ABSTRACT}

\section{Introduction}

Bullying, which is an important public healthcare issue, was defined as "a student or students exposing another student or students to negative impacts with deliberate, continuous or unequal power imbalances" (CDC, 2020; Olweus, 2003; Srabstein ve Leventha, 2010). Bullying can be in the form of physical bullying, which consists of behaviors such as hitting and kicking; verbal bullying, which consists of naming, ridiculing, and humiliating behaviors in the community; and cyber bullying, which consists of threatening the personality and property of a person through technology (CDC, 2020). Bullying students have characteristics such as being aggressive with a tendency to violence, a desire to show them strong, show little empathy, have anxious and insecure facial expression, be satisfied with hurting and harming others, be antisocial, have poor parental relations, and not obey school rules (Olweus, 1994; Banks, 1997). It was argued that students who are bullied (victims) experienced feelings of anxiety, anger, loneliness, being pushed out of the group and helplessness, not wanting to go to school, the emergence of some chronic diseases, or even attempting suicide. Also, it was determined that students who were bullied had increased absenteeism at school, preferred to stay at home, and their academic achievement and self-esteem scores decreased (Pişkin, 2002).

Although there are different estimations regarding the prevalence of bullying at the global level, it is generally reported to be between 13\% and 75\% (CDC, 2014). Bullying behavior is most common at secondary schools (28\%), high schools (16\%), mixed schools (12\%), and primary schools (9\%) (CDC, 2020). It was reported in previous studies that that one in three students between the ages of 13-15 is involved in a physical fight, half of the children are subjected to peer violence in and around the school, costing seven trillion dollars on a global scale (UNICEF, 2018). According to the PISA 2015 Report of the Organization for Economic Development and Cooperation (OECD), 18.6\% of students were subjected to any form of bullying at least several times a month in Turkey, 9.2\% were made fun of at least a few times a month by other students, and $4.5 \%$ were hit or poked by another student at least several times a month.

It is already known that public healthcare nurses have key roles in school healthcare (Avşar ve Ayaz Alkaya, 2018). Public healthcare nurses can be effective in preventing peer bullying at schools by using their roles as educators, advisors, advocates, change agents, and leaders. They can also play active roles in creating a holistic environment between the school, family, students and teachers with the programs they perform (Avşar ve Ayaz Alkaya, 2018). Public healthcare nurses must have adequate levels of knowledge to prevent bullying at schools, know its effects on bullies, victims, bully-victims and audiences, the ability to observe, train 
school staff and students, identify disadvantaged groups such as the disabled and obese who may be exposed to bullying, have effective communication skills, and the skills to include families in the programs implemented at schools and to make prevention programs (Özbey ve Başdaş, 2020). The purpose of this systematic review was to present the contents of schoolbased education programs to prevent bullying behaviors at schools, to examine their effects, and to provide guidance to school healthcare nurses. For this purpose, answers to the following questions were sought.

- What were the school-based quasi-experimental and experimental studies intended to prevent bullying behaviors between 2016-2021?

- What is the evidence level of the study results?

- Were the school healthcare nursing interventions performed to resolve the problem clearly stated in these studies?

\section{Method}

The Preferred Reporting Items For Systematic Reviews and Metaanalyses Statement (PRISMA), which is a valid and reliable guide for systematic reviews, was used to summarize the present review (The PRISMA Statement, 2021).

The study was conducted by reviewing the publications on the subject in electronic databases retrospectively. In this context, an in-depth literature review was performed by using the Academic Search Complete (EBSCOHOST) Database, which is one of the 10 databases providing access to publications on health sciences in PUBMED, Wiley Online Library, Sciencedirect, and Ege University Library information network. The studies conducted between January 1, 2016 and January 1, 2021 in these databases were searched with the keywords of "bullying, violence, nursing school health, children, training, intervention, prevention". As a result of the search conducted with these keywords, 1470 studies were found by making restrictions in the form of history, academic journals, randomized controlled studies, intervention studies, and school-based studies in Pubmed (7 Results), Sciencedirect (110 Results), Wiley Online Library (375 Results), and Academic Search Complete (EBSCOHOST) (978 results) databases. Among these 1470 studies, 90 randomized and semi-experimental studies were found; however, since 39 of these studies were not available as full text, 51 randomized and quasi-experimental studies were examined.

\section{Inclusion criteria for the articles to be included in the study}

- Prevention studies for peer bullying at primary, secondary and high school level, the study having an experimental or quasi-experimental design. 
- Availability of the full text, training program being implemented in school, school-based training programs, the language of publication being English.

- Providing the problem, intervention, comparison, and outcome (PICO) steps.

\section{Exclusion criteria}

Studies with non-experimental study design, qualitative studies, reviews, systematic reviews, cross-sectional studies, case reports, meta-analyzes, letter to editors, and books.

\section{Results}

The summary of the findings of the 51 studies evaluated in terms of the year, purpose, sampling, attempts and results titles are summarized in Table 1.

\section{Author / Year and Design Information}

When the studies included in the study were examined according to the countries in which they were conducted, it was found that 15 were conducted in the United States of America (USA), 5 in Turkey, 5 in Italy, 4 in England, 2 in Austria, 2 in Finland, 1 in Netherlands, 1 in Germany, 1 in Greece, 2 in Japan, 1 in South Africa, 1 in Canada, 2 in Spain, 2 in Norway, and 1 in New Zealand, 1 in Nigeria, 1 in Indonesia, 1 in Poland, 1 in India, 1 in China, 1 in Portugal, and 1 in Belgium. Among the studies reviewed here, 16 were published in 2016, 8 in 2017, 6 in 2018, 16 in 2019, and 5 in 2020; and 15 of them were conducted in randomized controlled design, and 36 in a quasi-experimental design.

It was determined that the procedures used in these studies varied according to the characteristics of their target populations. Procedures such as videos, posters, training curriculum applied for certain periods, conferences, group discussions, group works, and KIVA, OLWEUS, STAC, which were developed specifically for the target audience, were used in these studies (Table 1). Initiatives aimed at developing behaviors, such as developing self-esteem and self-efficacy skills, empathy, and preventing bullying behaviors were aimed in these procedures aimed at students. Initiatives aimed at awareness, intervention in bullying behaviors, and cooperation with families were targeted in initiatives aimed at teachers. Social support to students and improving school-family cooperation were focused in initiatives for families. It was emphasized in these studies that school health nurses contributed positively to the prevention of bullying behaviors, such as increasing the academic achievements of students, increasing school adaptation, belonging to the school, positive self-esteem, increasing motivation at school, decreasing absenteeism in school, increasing assertiveness in students, and decreasing the number of victimized students. It was also mentioned that the skills of school health nurses in 
preventing bullying should be increased. For this reason, the results obtained contribute to the literature.

\section{Discussion \& Conclusion}

Specially designed training programs called STAC, Theory of Reasoned Action (TRA)Video-based, the Student and Family Office (SFO), No Trap, Video-Based DT - SVM, OLWEUS, and KIVA were used in quasi-experimental studies. These programs are generally student-centered and are prepared for a short period of time. Randomized Controlled Studies, like quasiexperimental studies, are the Cyber Friendly Schools (CFS), KIVA, My Teaching Partner Secondary (MTP-S), No Trap, CORE, Matters, STAC, Then Active-Start, The ABBL, SEHER and Playgrounds. Although there are programs designed for this purpose, the KIVA training program was used more often. It was determined that Randomized Controlled Studies were long-term and their sampling sizes were higher compared to other studies, and the focus was on skill development in students.

In the present review, quasi-experimental studies were found to be generally short-term studies, and randomized controlled studies were long-term studies. Among the studies evaluated here, it was found that especially randomized controlled studies were effective in preventing bullying behaviors of students, and that KIVA and OLWEUS training programs, which were specially designed in these randomized controlled studies, yielded school, family and student-centered and long-term effective results. The studies focused especially on middle school and high school students. In the study, it was found that conducting some programs based on behavioral models provided support for the implementation of the programs more systematically. Because of the databases reviewed in the study, disadvantageous studies could not be reached at adequate levels. As a conclusion, the studies examined in this systematic review contributed to the literature in preventing bullying behaviors. It also guides school healthcare nurses and other researchers. There is a need for model-based, long-term, evidencebased studies for disadvantaged groups, involving parents and school staff to evaluate the effects of school-based bullying behavior prevention programs. 